IZA DP No. 9339

Migrant Networks and Job Search Outcomes:

Evidence from Displaced Workers

Tommaso Colussi

September 2015 


\title{
Migrant Networks and Job Search Outcomes: Evidence from Displaced Workers
}

\author{
Tommaso Colussi \\ $I Z A$ and $f R D B$
}

Discussion Paper No. 9339

September 2015

\author{
IZA \\ P.O. Box 7240 \\ 53072 Bonn \\ Germany \\ Phone: +49-228-3894-0 \\ Fax: +49-228-3894-180 \\ E-mail: iza@iza.org
}

\begin{abstract}
Any opinions expressed here are those of the author(s) and not those of IZA. Research published in this series may include views on policy, but the institute itself takes no institutional policy positions. The IZA research network is committed to the IZA Guiding Principles of Research Integrity.

The Institute for the Study of Labor (IZA) in Bonn is a local and virtual international research center and a place of communication between science, politics and business. IZA is an independent nonprofit organization supported by Deutsche Post Foundation. The center is associated with the University of Bonn and offers a stimulating research environment through its international network, workshops and conferences, data service, project support, research visits and doctoral program. IZA engages in (i) original and internationally competitive research in all fields of labor economics, (ii) development of policy concepts, and (iii) dissemination of research results and concepts to the interested public.
\end{abstract}

IZA Discussion Papers often represent preliminary work and are circulated to encourage discussion. Citation of such a paper should account for its provisional character. A revised version may be available directly from the author. 
IZA Discussion Paper No. 9339

September 2015

\section{ABSTRACT \\ Migrant Networks and Job Search Outcomes: Evidence from Displaced Workers ${ }^{1}$}

This paper investigates how immigrants' job search outcomes are affected by the labor market outcomes of workers from the same country of origin they are connected to. Connections are identified based on having worked for the same firm in the past. Using matched employer-employee micro data from Italy and an instrumental variables approach, I show that an increase in the employment prospects of socially connected workers improves immigrants' job search outcomes. The analysis of post-displacement outcomes sheds light on the different mechanisms generating the social effect.

JEL Classification: J61, J63

Keywords: migration, job displacements, networks

Corresponding author:

Tommaso Colussi

IZA - Institute for the Study of Labor

Schaumburg-Lippe-Strasse 5-9

53113 Bonn

Germany

E-mail: colussi@iza.org

\footnotetext{
${ }^{1}$ I am particularly indebted to Marco Manacorda for his guidance. I thank Ghazala Azmat, Vittorio Bassi, Tito Boeri, Richard Dickens, Benjamin Elsner, Francesco Fasani, Tommaso Frattini, Winfried Koeniger, Barbara Petrongolo, Federico Picinali and Olmo Silva for many insightful comments. My thanks to seminar participants at MILLS - Milano Cattolica, 10 $10^{\text {th }}$ IZA-AM $^{2}, 2013$ NORFACE-Cream, $27^{\text {th }}$ EEA and 2012 EALE conferences, II fRDB Workshop, QMUL Economics Reading Group, and to Giuseppe Tattara for providing the data. Support from the Fondazione Rodolfo Debenedetti and the Royal Economic Society is very gratefully acknowledged.
} 


\section{Introduction}

Social networks play a key role for immigrant job seekers for several reasons. First, as migrants are often newcomers in the labor market, personal contacts help them overcome information asymmetries generally affecting inexperienced workers. Second, immigrants may systematically rely on personal contacts while unemployed as many of them come from lowincome countries where social networks are one of the major sources of job information and support (Munshi, 2003).

Figure 1 plots the share of private sector employees who received information about their current job through their acquaintances across a number of European countries. ${ }^{2}$ On average more than one third of the workers in Europe report that they have obtained their current job through informal channels, i.e. through friends or relatives (Pellizzari, 2010); this share becomes higher when foreign-born workers are considered: in Italy for instance, about $42 \%$ of immigrants found their current job through personal contacts, compared to a figure for natives of $31 \%$.

Many studies find that non-native individuals tend to interact mainly with individuals of the same ethnicity (Bertrand et al., 2000; Marmaros and Sacerdote, 2006; Bandiera et al., 2008) and that recent immigrants typically locate where earlier immigrants from the same sending country live and work, giving rise to ethnic clusters (Card, 2009). Individuals from the same country of origin provide valuable information and support, in turn possibly leading to positive labor market outcomes. In particular, employed network members might provide information on job openings (Calvo-Armengol and Jackson, 2004) or directly refer workers to their employers (Montgomery, 1991; Dustmann et al., 2010), eventually increasing the arrival rate of job offers (Goel and Lang, 2010). ${ }^{3}$

A higher employment rate among network members though might also have the opposite effect, as greater network support could reduce job search effort, resulting in longer unemployment duration. General equilibrium effects might also be at work, due to competition in the labor market, possibly offsetting the potential benefits stemming from clustering (Beaman, 2012). Ultimately, segregation might reduce the pace of integration and lead to poor

\footnotetext{
${ }^{2}$ Data come from The European Community Household Panel, which is a longitudinal dataset covering 15 countries of the European Union for the period 1994-2001. Several countries, like Luxembourg, Sweden, Finland, Austria and Denmark are excluded from the sample as they are not covered in all the waves. The precise question asked in this survey is: "By what means were you first informed about your current job? ". Respondents then have six mutually exclusive alternatives, which include "Friends, family or personal contacts".

${ }^{3}$ Workers, both employed and unemployed, often use their personal contacts to acquire information about job vacancies; similarly, firms tend to rely on employee referrals as they reduce information uncertainties when screening new job applicants (Ioannides and Dacther Loury, 2004).
} 
labor market outcomes, as it may lower the speed at which immigrants learn host country skills and language or reduce the incentives to relocate to areas where labor demand is stronger (Lazear, 1999; Edin et al., 2003; Boeri et al., 2011).

Whether overall an increase in the employment prospects of socially connected individuals improves or harms job search outcomes among the unemployed remains an open question. This work precisely addresses this issue by focusing on immigrant networks and estimating the effect of changes in the current employment rate of past co-workers from the same country of origin on unemployed individuals' job search outcomes. For this exercise I use matched employer-employee micro data from the administrative records of the Italian Social Security Administration (INPS), which cover the universe of private non-agricultural dependent employment relationships between January 1975 and December 2001.

Identifying the effect of social networks on workers' job search outcomes poses fundamental identification issues. First, because of task and job specialization along country of origin lines and because of geographical clustering, migrants from the same country tend to be exposed to similar labor demand shocks, a classic case of correlated effects (Moffitt, 2001). A positive correlation between a worker's employment status and the employment rate of his coworkers may be driven for example by shocks affecting only specific groups in the same occupation or working in the same local labor market. Second, migrants who tend to cluster with employed individuals might be systematically different; for example, being the ones most benefiting from group membership, a classic case of endogenous group formation, possibly leading to biased estimates of social effects. Finally, reflection plagues any credible attempt to identify social effects (Manski, 1993; Moffitt, 2001; Soetevent, 2006).

In order to get causal estimates of the effect of social networks, I focus on displaced workers as their decision to work is arguably exogenous. For each of these workers I define a network as the group of past co-workers from the same country of origin in the five years preceding the displacement. I then instrument each network member's employment status by his own displacement episode up to the month before the pivotal worker's displacement episode. A well-established body of literature shows that job loss episodes have long-lasting consequences on employment (von Wachter and Bender, 2007). As long as past displacements are uncorrelated with a worker's characteristics, both those that are correlated with socially connected individuals' latent employment outcomes and those affecting the propensity to form a group, this instrumental variable approach will lead to consistent estimates of the effect of interest. 
Empirical findings show that, among immigrants who lost the job, a 10 percentage point increase in the current employment rate of previous co-workers from the same country of origin raises the probability of re-employment within 36 months by 5.7 percentage points. Separate regressions for low skilled and inexperienced immigrants show that these categories of workers gain the most from the support of past co-workers. The social effect is significant only for immigrants coming from non-OECD countries, where formal labor markets are less developed and where non-market institutions are likely to be prevalent. Further, the magnitude of the social effect increases after the second year following the lay-off: networks appear to constitute an important resort particularly for immigrants with limited access to employment opportunities (Datcher Loury, 2006).

Interestingly, I find no evidence of any effect of changes in the employment rate of past co-workers from countries of origin other than the workers' own. Moreover, results show that even among natives there is a positive effect of the network employment rate; however, this effect is significantly smaller than the one found for immigrants, suggesting that migrants tend to rely on their co-worker networks in job search more than natives.

The analysis of post-displacement outcomes sheds light on the different mechanisms behind the estimated network effect. I show that when the network employment rate increases by 10 percentage points, the probability that displaced migrants find a job within 36 months since job loss in connected municipalities and firms (i.e. firms or municipalities in which at least one past co-worker has ever worked) increases by 7.9 and 5.1 percentage points respectively. These last findings are consistent with the interpretation that migrant networks facilitate the job search of displaced members by providing them with information about job vacancies.

The paper contributes to the growing empirical evidence on the role of coworker-based networks in labor markets (Cingano and Rosolia, 2012; Glitz, 2013; Hensvik and Skans, 2014) by specifically focusing on immigrants who have received little attention by this literature. Studying migrant networks also has several advantages in terms of identification, as the country of origin provides a reasonable proxy for who your friends are during the network building phase. This work also relates to the small body of literature on ethnic segregation in labor markets, and in particular to the role of networks in explaining minority concentration across establishments and occupations (Aslund and Skans, 2010; Patel and Vella, 2013).

The rest of the paper is structured as follows: Section 2 describes the data and it provides summary statistics. Section 3 discusses the research design and the identification issues. 
Section 4 reports the main results and a set of robustness checks. Section 5 analyses post displacement outcomes of displaced migrant workers. Finally, Section 6 concludes.

\section{Data and Summary Statistics}

The data used in this paper are matched employer-employee micro data from the administrative records of the Italian Social Security Administration (INPS) for the Italian region of Veneto. The data cover the universe of private non-agricultural dependent employment relationships between January 1975 and December 2001. ${ }^{4}$ This dataset has been used by a number of other papers; among others, Card et al. (2014) test the degree of rent sharing by workers in Italy. ${ }^{5}$

Veneto is one of the twenty-one Italian regions (administrative divisions corresponding roughly speaking to USA states) encompassing seven provinces (roughly a USA county) and 581 towns. ${ }^{6}$ As of 2011, Veneto had a population of about 4.9 million, accounting for about $8 \%$ of the total Italian population and 9\% of national GDP. ${ }^{7}$

The primary unit of observation in the data is a firm-worker match per calendar year. In other terms, for each employment relationship, there are as many observations in the data as the number of calendar years over which this relationship spans. In each calendar year, there can be multiple observations by individual, as individuals can hold more than one job, whether simultaneously or sequentially, during the same year. The data provide information about start and end dates of any employment relationships, the total yearly compensation, the number of working weeks, the type of contract (part-time vs. full time), worker's occupation, age, gender, and municipality of residence at the time of the first job in Veneto, sector of activity (at the 3 digit level) and the municipality where the firm is located. ${ }^{8}$ The INPS data also provide detailed information on country of birth (overall, 154 countries) ${ }^{9}$

\footnotetext{
${ }^{4}$ Although the data primarily include private sector workers, they also contain information on public sector workers who have fixed term contracts, such as substitute teachers, health professionals and nurses.

${ }^{5}$ Cingano and Rosolia (2012) use a similar version of this dataset that encompasses only two provinces.

${ }^{6}$ This dataset contains 7,675 municipalities as workers originally observed in Veneto may be subsequently employed in any Italian municipalities outside Veneto. As of 2011, in Italy there were about 8,200 municipalities. ${ }^{7}$ Veneto is located in the north east of the Italy, the major municipalities, in terms of population, are Venice (270,000 inhabitants), Verona (263,000 inhabitants) and Padua (214,000 inhabitants). The most industrialised cities are Verona, Vicenza, Padua, Treviso, characterized by small firms, operating in different areas of manufacturing: food products, wood and furniture, leather and footwear, textiles and clothing, gold jewelery. Venice and Rovigo are instead specialized in energy, chemical and metal processing. Tourism also plays an important role in the region's economy: Veneto is the first region in Italy in terms of tourist presence, accounting for one-fifth of Italy's foreign tourism. Tattara and Anastaisa (2003) provide a report on Veneto's economy.

${ }^{8}$ The dataset is composed of three archives: a "worker" archive in which all the time invariant characteristics of the workers are included, such as the date and the country of birth, the gender and the municipality of residence at the time he started to work in Veneto; a "job" archive, in which information on the employment relationships is provided. Whenever an employment relationship changes, because of an upgrade or switch from part time to full time, a new record is created. The third archive contains information on the firm, its industry code (3-digit), the
} 
The data exclude self-employed individuals or those employed in family businesses for which registration at INPS archive is not required. Both workers and firms in the data are individually identifiable and can be followed over time. Workers originally observed in Veneto who are subsequently employed anywhere else in Italy are also followed in the data. The absorbing state hence includes non-employment, death, movements to other countries (including the home country for non-natives), self-employment, public sector employment and informal employment. The original dataset includes information on around 3.6 million workers for a total number of approximately 12.5 million employment relationships in more than 1.1 million firms.

\subsection{Immigrants in Veneto's Labor Market}

While being one of the largest sources of immigration to the USA and the rest of America in the early twentieth century and a traditional source of internal migration up to the 1970, Veneto has witnessed a large influx of international migrants in the last thirty years, currently being one of the favored destinations among international migrants to Italy. Between 1990 and 2001, the number of immigrants in the population increased almost three-fold, from around 50,000 to more than 140,000 out of a total population of 3.5 million. In 2001 the share of migrant population in Veneto was about 4\%, well above the national average of $2.3 \%$ (Anastasia et al., 2001; Venturini and Villosio, 2008).

Figure 2 plots the evolution of foreign workers presence in Veneto since 1975 based on INPS data: the share of migrants among formal non-agricultural private sector employees in Veneto started increasing rapidly after 1990, the highest increase being between 1995 and 2000, following two large regularizations of illegal immigrants. This pattern is in line with immigration trends in Italy: from 1970 to 2000 the number of foreign workers has increased from about 150.000 to 1.3 million. $^{10}$

Figure 2 also shows that the origin of immigrants has varied significantly over the period considered: the share of immigrants from EU15 countries has decreased (from about 47\% in 1975 to $16 \%$ in 2001), while the share of immigrants from the Balkans and North Africa has increased, the most numerous immigrants' groups in 2001 being Moroccans, citizens of former Yugoslavia and Albanians, respectively with shares equal to 12.7\%, 9.4\% and 7.3\%.

municipality in which the firm is located and its post code. If a firm changes location or sector of activity a new record is created.

${ }^{9}$ Data only refer to foreign born individuals, including legal immigrants with a work permit currently employed as formal employees. The data exclude all the undocumented migrants working in Italy, which are estimated to account for about $10 \%$ to $40 \%$ of the regular foreign workforce (Venturini and Villosio, 2008). See Appendix B for a brief summary of immigration policies in Italy.

${ }^{10}$ For an extensive review of immigration trends to Italy see Ministero dell'Interno (2007). 
Table 1 presents averages over the entire period of the main variables in the dataset by immigration status (migrants vs. natives). Immigrants represent about 7 percent of the individuals in the sample. ${ }^{11}$ Since migration to Veneto is a recent phenomenon, most foreign workers appear in the last years of observation, partly explaining why the average length of employment spells is shorter among migrants than natives. About 58\% of migrants who ever worked in Veneto are present in the last year of the dataset (the corresponding figure for natives is $45 \%$ ), and the average length of the spell is half the one for natives. The shorter duration of job matches among migrants however is also indicative of migrants switching jobs more frequently. Indeed transition rates show that migrants have both higher exit and entry rates from and into employment than natives: the monthly exit rate for natives is $1.7 \%$ while for migrants this is $3.2 \%$. Entry rates for natives and immigrants are respectively $1.68 \%$ and $3.14 \%$, suggesting that immigrants are more mobile in the labor market and tend to end up in more precarious jobs than natives.

Table 1 also reports information on the gross weekly wage; values are expressed in real terms (Euros of 2003) and are comprehensive of all payments including overtime and bonuses. Immigrants' weekly wages are lower than natives’ by about 29 Euros, roughly 4\%. Migrants tend to be employed in low skilled occupations and in smaller firms, which pay lower wages and have fewer restrictions in firing decisions. ${ }^{12} 72 \%$ of migrants are blue collars workers compared to $63 \%$ of natives; the average number of co-workers in the sample is 213 for migrants and 481 for natives. Immigrants are more likely to work for firms in which other migrants are also employed: the number of foreign co-workers is 26 for migrants and 13 for natives.

Table 2 explores key characteristics of firms and municipalities in the data. Veneto firms are in general very small: the average firm size is equal to about seven employees. ${ }^{13}$

The Table also reports values of two measures of segregation of migrants: the dissimilarity and the isolation indexes. ${ }^{14}$ The dissimilarity index, also known as the Duncan index of

\footnotetext{
${ }^{11}$ According to Venturini and Villosio (2008), in 2001 in Italy there were 1.4 million foreign workers, representing about $6 \%$ of the total workforce. This share in the northern regions was higher than the national average, being equal to $7.3 \%$.

${ }^{12}$ In Italy a law regulating employment relationships, the "Chart of Workers' Rights" (Law No. 300: Statuto del Lavoratori) of 1970, introduced norms that restrict firing decisions of firms with more than 15 employees. In case of unfair dismissals, firms are forced to take back the displaced employee and to pay him his full wage before the lay-off. Moreover firms are fined up to $200 \%$ of the displaced workers' original wage for the delayed payment of contributions.

${ }^{13}$ Italy is characterized by a multitude of small firms and few big companies; the Italian average firm size is equal to 10.5 employees (Bartelsman et al., 2003).

${ }^{14}$ Segregation is defined as the degree to which two or more groups live or work separately from one other (Massey and Denton, 1988).
} 
segregation, tells us whether immigrants are evenly distributed over firms or municipalities. The index is defined as:

$$
D I=\frac{1}{2} \sum_{i=1}^{N}\left|\frac{\text { Migrants }_{i}}{\text { Migrants }_{\text {Total }}}-\frac{\text { Natives }_{i}}{\text { Natives }_{\text {Total }}}\right|,
$$

where $i$ is the unit of analysis, i.e. the firm or the municipality of work, Migrants $i$ is the number of all immigrants employed in unit $i$, Migrants ${ }_{\text {Total }}$ is the number of all migrant workers in the population; Natives ${ }_{i}$ is the number of Italian workers in unit $i$ and Natives ${ }^{\text {Total }}$ represents the total Italian workforce in the dataset. This index reports the share of migrant workers that would have to move to different firms (or cities) in order to produce a distribution that matches the one of natives. It ranges from zero, when all the units have the same relative number of migrants and natives, to one, i.e. complete segregation. Following Cutler et al. (1999), values of this index higher than 0.6 imply high levels of segregation.

However, even if migrants evenly work in firms and cities relative to natives, it does not mean that they frequently interact with natives. For instance, immigrants can be evenly distributed among firms but have few contacts with natives if their share in the overall population is relatively large. The isolation index measures the exposure of migrants to natives; it indicates the amount of potential contacts and interactions between immigrants and natives within firms or cities. The index is defined as:

$$
I I=\frac{\sum_{i=1}^{N}\left(\frac{\text { Migrants }_{i}}{\text { Migrants }_{\text {Total }}} * \frac{\text { Migrants }_{i}}{\text { Workforce }_{i}}\right)-\frac{\text { Migrants }_{\text {Total }}}{\text { Workforce }}}{1-\frac{\text { Migrants }_{\text {Total }}}{\text { Workforce }}}
$$

where $i$ is the unit of analysis and Workforce $_{i}$ is the number of all the workers in unit $i$ irrespectively of the country of origin. The first term in the numerator, $\sum_{i=1}^{N}\left(\frac{\text { Migrants }_{i}}{\text { Migrants }_{\text {Total }}} * \frac{\text { Migrants }_{i}}{\text { Workforce }_{i}}\right)$, is the typical exposure index (Massey and Denton, 1988), which has been adjusted by subtracting the share of migrants in the total working population of Veneto, i.e. $\frac{\text { Migrants }_{\text {Total }}}{\text { Workforce }}$. Indeed, when immigrants in the population are few it would be impossible for them to be completely isolated, this adjustment then eliminates the effect arising from the overall size of the migrant population. The adjusted exposure index has eventually been rescaled by $1-\frac{\text { Migrants }_{\text {Total }}}{\text { Workforce }}$ so that we get a measure of isolation ranging 
between zero and one. Typically, values of this index higher than 0.3 suggest that immigrants are highly isolated (Cutler et al.; 1999).

From Table 2 there is evidence of low segregation at municipality level, with a Duncan index equal to 0.25 , meaning that about one fourth of the all migrants would have to move municipality in order to produce a distribution that matches that of the natives. The index substantially increases when the unit of analysis is the firm: more than half of migrant workers have to switch firm in order to have no segregation at the firm level. The same pattern applies to the isolation index, the level of exposure significantly increases when the unit of analysis is the firm, being the index equal to 0.27 . In sum, despite the relatively low level of residential segregation, immigrants seem to be highly segregated at the firm level.

Figure 3 further explores segregation at the city level separately by country of birth; in this figure only the most numerous groups are included. Segregation increases when the Duncan index is separately computed by country of origin. The least segregated migrants come from France (25.2\%) while the most segregated are from Ghana (45.3\%). Dissimilarity between minority groups is also high: for example, workers from former Morocco are equally segregated from Italians (32.7\%) as they are from Yugoslavians (31.9\%).

\subsection{Closing Firms and Displaced Workers}

In the rest of this section I focus on displaced workers, i.e., those who lost their job because of a firm closure. Overall $16 \%$ of the firms do not survive to the last year of observation. ${ }^{15}$ Closing firms are in general smaller than the rest as they employ on average 4.8 employees.

Of the 261,399 migrants ever observed in data in the period 1975-2001, 16,857 were laid off because of a firm closure. Some of them were displaced more than once, giving a total of 18,267 displacement episodes. Relative to the entire sample of workers, displaced workers are younger, more likely to be female, earn lower wages and more likely to be employed in unskilled occupations. Compared to natives, migrants have a higher propensity to be displaced: the share of workers displaced every month, i.e. the transition from employment to non-employment due to firm closure, is $0.14 \%$ among migrants and $0.10 \%$ among natives. Not only is the monthly displacement rate higher for migrant workers but, conditional on displacement, re-employment probabilities are lower: among displaced workers $49 \%$ of the natives find a job in the first 3 months following a firm closure, while the same figure for migrants is $46 \%$.

\footnotetext{
${ }^{15} \mathrm{~A}$ firm closure is recorded whenever a firm shuts down; in the dataset a specific variable indicates the (monthly) date at which a firm stops its business and thus disappears from the sample. This variable also distinguishes between real closure and other events affecting a firm's business other than closures, such as changes in the name and in the organization, breaks up, mergers and acquisitions.
} 
Figure 4 shows the effect of displacement episodes on subsequent employment probabilities of migrant displaced workers. It plots the coefficients of a regression in which the employment probability is a function of individual characteristics, such as age and gender, as well as time exposure dummies for each of the 36 months before and after the closure. ${ }^{16}$ While there is no clear pattern before the displacement episode, Figure 4 displays a strong persistence of displacement, on subsequent employment outcomes; even after 36 months, the probability of finding a job is negatively affected by the firm closure. Regressions are run separately for immigrants and natives: the persistence of the displacement effect does not vary by immigration status; however, it seems that natives recover slightly faster than migrants after job loss. For both immigrant and native workers the consequences of displacements on successive labor market performances appear to be long lasting.

\section{Empirical Strategy}

To estimate the effect of social connections on individuals' employment outcomes I restrict the analysis to workers that lost their job because of a firm closure. This set-up allows comparing workers who are similar because they entered unemployment following exogenous job loss and simultaneously started using their network to find a new job. Focusing on displaced workers thus helps reducing potential biases arising from the endogeneity of job changes in the estimation of the social network effect (Gibbons and Katz, 1992).

This section presents a linear-in-means model in which the re-employment probabilities of unemployed workers depend on the both employment rate and the observed characteristics of network's members:

$$
y_{i t}=\beta_{0}+\beta_{1} \bar{y}_{-i t}+\bar{x}_{-i t}^{\prime} \beta_{2}+x^{\prime}{ }_{i t} \beta_{3}+u_{i t}
$$

where $y_{i t}$ is a dummy variable equal to one if worker $i$ is in employment at time $t ; \bar{y}_{-i t}$ denotes the network's employment rate at time $t$, and $x_{i t}$ and $\bar{x}_{-i t}$ are vectors of individual and network characteristics respectively. For each individual $i$, a network is defined as the group of past co-workers from the same country of origin in the five years preceding the displacement.

The coefficient $\beta_{1}$ captures the endogenous social interaction effect. Least squares estimates of this coefficient can be biased because of correlated effects i.e. the presence of institutional environments or common unobserved individual characteristics that lead to spurious correlations among group members' behaviors. This is for example the case of

\footnotetext{
${ }^{16}$ The estimated equation is $y_{i t s}=\alpha+\sum_{k=-36}^{+36} \delta_{k} D_{i k}+\lambda_{i}+\varepsilon_{i t s} . D_{i k}$ are dummies for a worker's time exposure for each month $t$ before and after displacement, i.e. $\boldsymbol{D}_{\boldsymbol{i k}}=\mathrm{I}[\mathrm{t}-\mathrm{s}>\mathrm{k}]$, where $s$ is the displacement date. All regressions include individual fixed effects, standard errors are robust.
} 
aggregate supply and demand shocks that equally affect workers from the same country of origin or those in a specific local labor market.

In an attempt to control for such correlation, regressions include a set of controls for observed workers' and environment characteristics, such as nationality, time of displacement, and municipality of first work in Veneto. As long as the network measure is worker-specific, it is possible to compare re-employment probabilities of individuals with different network employment rates who are otherwise identical because of their country of origin, time of job loss, and the initial location of work.

Another source of potential endogeneity arises from non-random sorting: agents might self-select into reference groups according to unobservable characteristics that simultaneously influence group membership and individual behavior.

Finally, reflection might lead to biased OLS estimates. In a network composed of two workers, $i$ and $j$, $i$ 's behavior will influence $j$ 's behavior and vice versa, implying that OLS estimates of equation (1) will pick up more than the causal effect of $j$ 's on i's behavior (Manski, 1993).

The identification of the endogenous effect is still possible by means of instrumental variables, where the instrument is an exogenous variable affecting $j$ 's outcome variable directly and $i$ 's outcome only through the endogenous social interaction. Following a wellestablished literature that shows long-term effects of displacement (von Wachter and Bender, 2007), in the rest I use past co-workers' displacement episodes as an instrument for their current employment status. In particular, I instrument a network member's employment status by his own displacement episode between the time the connection with pivotal worker $i$ was established and the month before the pivotal individual's displacement episode.

In practice I augment equation (1) with a dummy variable $z_{i t}$ equal to one if an individual was ever displaced up to period $t$. Clearly, because I restrict the sample to pivotal individuals $i$ who have been displaced, the variable $z_{i t}$ is equal to one in the main equation. The first stage equation then takes the following expression:

$$
\bar{y}_{-i t}=\gamma_{0}+\gamma_{1} \bar{z}_{-i t}+x^{\prime}{ }_{i t} \gamma_{2}+\bar{x}_{-i t}^{\prime} \gamma_{3}+e_{i t},
$$

where $\bar{y}_{-i t}$, the network employment rate, is regressed on the fraction of network members who were ever displaced between the time they first worked with individual $i$ and time $t$. This empirical strategy compares two similar workers who have had different work histories and thus different networks. In particular, these networks differ because each pivotal worker has a group of past co-workers who experienced a firm closure before his own displacement episode. 
The identifying assumption is that displacement episodes occurred to past co-workers only affect a worker's re-employment probability through the endogenous variable, i.e. the network employment rate. This instrumental variable estimate of the social interaction effect will be consistent if, as it seems plausible, firm closures are uncorrelated with a worker's characteristics that simultaneously affect both his and his network members' latent employment outcomes. Under this assumption, the instrumental variable approach will eliminate any residual endogeneity arising from unobserved network's characteristics. A set of falsification tests in Section 4 will provide evidence in support of this assumption.

I finally define the dependent variable $y_{i t}$ in equation (1) as a dummy variable equal to one for non-employment spells starting at $t$ which are concluded within a given time span (e.g. 36 months); while $\bar{y}_{-i t}$, the network employment rate, is the share of network members employed at the time of $i$ 's displacement episode. The instrumental variable, $\bar{z}_{-i t}$, is thus the share of network members that have experienced a firm closure before worker i's displacement episode. This instrument is worker specific and only considers job loss experienced by group members before individual i's displacement episode, thus excluding contemporaneous firm closures that may be correlated with individual $i$ 's displacement episode. The reflection problem does not represent an empirical concern in this empirical setting since groups of past coworkers differ across displaced immigrants (De Giorgi et al., 2010).

\section{The Effects of Networks: Empirical Results}

In the rest of the analysis, I focus on networks that are created at most five years before the displacement. Because of this, I drop the first five years of observation in the dataset (1975 to 1979) hence focusing on job loss episodes that occur not earlier than January 1980. Displacements occurring in the last three years (1999 to 2001) are also excluded so that workers can be followed for up to 36 months after job loss. If a worker experienced more than one closure, I only consider the first one, as the subsequent episodes are likely to be correlated with the first lay-off.

Eventually, the sample analyzed is composed of 10,738 workers who experienced a firm closure between January 1980 and December 1998. Excluding closures occurring in 1999, 2000, and 2001 decreases the sample size to 14,317. Moreover, dropping closures happening in the first five years of the dataset reduces the number of displaced immigrants to 13,194 . Finally, workers who experienced a closure while they were employed at the same time in another firm are excluded from the sample of displaced workers. 


\subsection{Baseline Specification}

Table 3 reports estimation results of model (1) and (2); controls include age, country of origin, and gender dummies for worker $i$ plus the averages of the same variables for network's members and a set of dummies for the size of the network. ${ }^{17}$ In addition, dummies for the month of displacement are added to the regressions. Standard errors are clustered by country of origin. ${ }^{18}$

Column (1) of Table 3 reports baseline IV estimates: the endogenous interaction coefficient, $\beta_{1}$, is positive and statistically significant at $1 \%$ level; this result suggests that past co-workers' employment status has thus a positive effect on the displaced workers' probability of finding a job in the 36 months after firm closure. This first specification includes month of displacement dummies; column (2) of the same Table additionally controls for the interaction between country of birth and the month of displacement, accounting for unobservable shocks that equally affect migrants from the same country that have been laid off at the same time. As country specific shocks are absorbed, the coefficient of interest falls in magnitude and significance but it remains positive and statistically significant.

Consistent with Figure 4, first stage regression estimates confirm the strong predictive power of the instrument; the bottom rows of Table 3 show that these estimates are very precise, being the value of the F-test (40.74) reasonably high. ${ }^{19}$

To further account for endogenous location choices, column (3) includes the interaction between nationality, date of displacement and the first municipality of work in Veneto; in practice I am comparing two individuals from the same country of origin, who started working in the same municipality and who have experienced a firm closure at the same time. Withincountry and within-municipality comparisons control for any spurious correlation due to unobservables that affect all individuals from the same country that started working in the same local labor market. ${ }^{20}$

The empirical evidence shows that social spillovers still persist: as more restrictive controls are added both the significance and the magnitude of the endogenous effect increase. The

\footnotetext{
${ }^{17}$ Network size dummies are defined as: 0, 1-5, 6-15, 16-49, 50+; results are robust to the inclusion of dummies for each value of the network size variable.

${ }^{18}$ This is the most restrictive specification: clustering at country level increases standard errors and it thus affects the significance of the coefficients. A less restrictive specification by country of origin interacted with the month of displacement has been tested in the regressions: the magnitude of standard errors decreases. The tables only report standard errors clustered by country of origin.

${ }^{19}$ Coefficients of the first stage regressions exhibit a positive sign because of the way the regression's sample is constructed.

${ }^{20}$ Controls for the first city of work account for migration intial location choices, ruling out any bias from nonrandom sorting into specific local labor market. Subsequent location decisions, including the one of displacement are likely to depend on the first one.
} 
more members employed in the network at the time of displacement, the higher the reemployment probability of displaced co-workers within 36 months following firm closure. The coefficient of the social effects tells that a 10 percentage point increase in the network employment rate raises the probability of finding employment within 36 months after job-loss by 5.7 percentage points. In other words, a one standard deviation rise, i.e. about 28 percentage points, in the network employment rate leads to a 34 percentage point increase in the 36 months re-employment probability. ${ }^{21}$

Social networks have thus a beneficial effect on re-employment probabilities of their displaced group members. Moreover, estimates of the endogenous effect are significant and positive in every specification adopted.

OLS regressions are presented in Appendix A: coefficients are always smaller than the ones reported in Table 3 suggesting that OLS estimates are downward biased. One possible explanation could be negative sorting into groups: high ability immigrants tend not to rely on their co-national past coworkers. Another plausible reason has to do with the fact that the variation in the IV estimates comes from job losses of individuals that are attached to the labor market and thus represent a valuable source of job information; on the other hand, OLS estimates are driven by all kind of job to non-employment transitions, including those of retired workers who are unlikely to act as referrals or information provider.

The next subsection aims at exploring the heterogeneity of the network effect by running separate regressions according to displaced workers' characteristics.

\subsection{Heterogeneity of the Network Effect}

Results in the first three columns of Table 3 impose that the social effect is constant across different types of migrant workers; however, it is reasonable to think that this network effect differs according to workers' characteristics, such as experience and tenure in the labor market.

As highlighted by several studies (Edin et al., 2003; Kramarz and Skans, 2014), less experienced immigrants are more prone to rely on their acquaintances, being thus the ones who benefit the most from the help of their co-workers. In order to test this hypothesis, I run separate regressions in which the sample of displaced workers is split according to their occupation and tenure at the time of displacement.

In columns (4) and (5) the sample is divided on the basis of the occupation of the pivotal individuals at the time of firm closure. Blue collar workers are analyzed in column (4), they

\footnotetext{
${ }^{21}$ In other terms, one more additional worker employed in a displaced worker's group at the time of displacement increases his chances of finding a job in the next 36 months following a firm closure by 12 percentage points.
} 
represent about $70 \%$ of the whole sample; while in column (5) I retain occupations other than blue collars, such as white collars and managers, accounting for the remaining $30 \%$ of displaced migrants.

Estimates indicate that immigrants employed in unskilled occupations are the only ones for which the endogenous social interactions are positive and significant: the coefficient of the network employment rate is equal to 0.54 and statistically significant at $5 \%$ level. There is no significant effect for other categories of workers, as shown by results in column (5).

To further explore the heterogeneity of the network effect, I focus on migrants' tenure in the Italian labor market. I define low-tenured immigrants those who have been employed less than 20 months prior the job loss, i.e. the median of the distribution of months in employment. The coefficient in column (6) is still positive and it increases in both significance and magnitude: a 10 percentage point raise in the network employment rate increases the 36 month re-employment probability of low tenured immigrants by about 9 percentage points. There is no significant effect for more experienced workers, as shown in column (7). ${ }^{22}$

Immigrants' use of their acquaintances may also vary depending on their country of origin. Whenever labor markets function imperfectly, non-market institutions, such as social networks, may emerge in order to contrast market failures. Personal contacts then represent the major source of job information and support for immigrants coming from less developed countries. Workers from those countries may systematically rely on their social networks also in the host country. I therefore split the sample in two subgroups depending on whether a worker's country of origin is an OECD member state. The coefficient of the network employment rate is positive and significant only when regressions are run for non-OECD countries; this result suggests that workers from least developed countries make a wide use of their personal contacts even after they moved to Italy. ${ }^{23}$

Regressions in Table 3 only analyze the network effect on re-employment probabilities within 36 months following a lay-off. However this effect may vary according to the time window considered. Figure 5 plots re-employment probabilities of displaced individuals in each of the 36 months following the displacement; because of censoring, the graph does not include displaced workers who have not found a job within 36 months, i.e. about $27 \%$ of the sample. Almost $30 \%$ of displaced migrants found a job within the very first month of unemployment, while only a small portion of workers are still non-employed after the first year following the layoff.

\footnotetext{
${ }^{22}$ First stage estimates are not significant for experienced immigrants other than blue collars, this may suggest that displacements do not affect the employment status of these two groups of workers.

${ }^{23}$ It is worth acknowledging that the estimated effect may vary across subgroups for many reasons (other than
} 
Figure 6 reports coefficients of the network employment rate from 36 regressions in which the dependent variable is, in turn, the cumulative re-employment probability from one to 36 months after job loss. ${ }^{24}$ As in column (3) of Table 3 I control for the interaction between the country of origin, the time of displacement and the first city of work; standard errors are clustered by country. The vertical lines in the graph depict the $90 \%$ confidence intervals.

The estimated coefficients actually change according to the different time intervals considered: they are mainly positive, becoming statistically significant only after the 22nd month since job loss. The effect appears particularly high within the first months following the displacement even though it is not statistically significant. After the 22nd month, the social effect stays positive and significant up to the 36th month.

One possible interpretation of these results is that immigrants use their personal contacts as a last resort when they are not able to find a job through the formal channel. However, a delayed effect of networks can be interpreted as a composition effect: low skilled displaced workers are the ones who rely the most on their personal contacts while looking for a job, as shown in Table 3, and they are also the ones who need more time to find a job and. ${ }^{25}$

\subsection{Falsification Test: Effects of Other Groups}

So far networks have been defined as groups of co-national past co-workers, relying on the assumption that immigrants tend to interact mainly with workers from the same country of origin. This section investigates whether co-workers from different nationalities provide the same valuable information in job search; in particular, I test if the employment status of past co-workers other than co-nationals affects the 36-month re-employment probability of displaced migrants. Past co-workers from other countries are likely to share the same unobserved characteristics as co-national co-workers, like the ones driving sorting into firms, but they are unlikely to provide valuable information in job search; finding a significant positive effect of employment status of co-workers from different nationalities would suggest sorting along unobservables. Estimates in Table 3 may still be driven by omitted characteristics that simultaneously affect individual $i$ 's probability of finding employment and his co-workers' probability of displacement rather than a genuine social effect; for instance, if low ability individuals self-select into firms with a high probability of closure, the

culture), which are correlated with the OECD dummy, such as occupational clustering.

${ }^{24}$ The graph reports estimated coefficient of the network employment rate for 36 regressions in which the dependent variable is, in turn, the probability of findind a job in $n$ months after displacement, where $n$ goes from 1 to 36 .

${ }^{25}$ Figure A1 in the Appendix plots re-employment probabilities of displaced individuals in each of the 36 months following the displacement by tenure in the labor market. Among low tenured displaced workers $41 \%$ do not find a job, while the same figure for high tenured is about $25 \%$. 
identification assumption would be invalid, as firm closures affecting group members could be correlated with unobserved characteristics of the pivotal displaced individual.

Table 4 presents estimates from regressions in which the re-employment probability of a displaced worker depends on the employment rate of past co-workers from other countries of origin. The first two columns of the Table focus on networks composed of past co-workers from other foreign countries (i.e. non-nationals), while in the last two columns networks only include native past co-workers (i.e. Italians). ${ }^{26} \mathrm{IV}$ regressions include average characteristics of past co-workers, as well as dummies for the size of the network. The interaction between the country of origin, the month of displacement and the first city of work is added as a control.

The estimate of the effect of non-national co-workers' employment status on the individuals' re-employment probability is positive but not significant in column (1), where I only include the interaction between the country of origin and the month of displacement. When I additionally control for endogenous location choices, i.e. column (2), the sign of the coefficient turns negative but it is still not significant. It is also interesting to notice that the coefficients of the employment rate of the non-nationals are always smaller in magnitude than the ones of the co-nationals found in Table 3. These results indicate that there is no evidence of significant social interactions among co-workers of different nationalities; further, the negative sign for the coefficient in column (2) suggests that immigrants, who used to be coworkers but from different nationalities, rather compete for the same job vacancies.

Columns (3) and (4) of Table 4 analyze networks composed of Italian past co-workers. Regressions still compare two individuals from the same country of origin, who have experienced a firm closure at the same time, however the network does not include any migrant past co-workers. Results are similar to the ones found when non-nationals are taken as reference group: the coefficient of the social effect is positive but not significant. As more restrictive controls, i.e. the first city of work, are added, the sign of the coefficient turns negative but it is still not significant. Interestingly, the estimated coefficients when the reference group is only composed of Italians are always smaller than the ones found when immigrants are included in the reference group. This difference in magnitude may indicate that interactions between natives and immigrants are occasional, either because of preferences (or tastes) or because they end up working in different occupations or firms. First stage

\footnotetext{
${ }^{26}$ From now onwards I will refer to co-workers from the same country of origin of the pivotal displaced worker as co-nationals, the ones from different countries of origin (excluding Italians) as non-nationals and Italians for the natives past co-workers.
} 
regressions again confirm that the instrument has a strong predictive power, which is particularly performing when natives are considered as a reference group. ${ }^{27}$

Reassuringly, regressions in Table 4 produce not significant coefficients in any specifications adopted: the positive social effect found for co-national networks is not biased by omitted variables affecting workers that have worked together in the same firm. If there were sorting, generating spurious correlation leading to a significant network effect as in Table 3 , then the effect of non-national past co-workers would have been significant. These results then confirm the validity of the instrument used, which manages to solve potential biases coming from the endogenous group formation.

\subsection{Social Effects among Natives}

In previous Sections I only focus on interactions among immigrants; however, Figure 1 shows that in every European labor market native workers also rely on their personal contacts while looking for a job. Moreover, previous studies report that a positive network effect also exists among natives; Cingano and Rosolia (2012), using an earlier version of these data, provide evidence of significant and robust network effects on unemployment duration of native workers. Similarly, Glitz (2013) using data on employees in Germany, finds a strong positive effect of a higher employment rate in a worker's network on his re-employment probability after displacement.

This section explores whether endogenous interactions take place among natives and how this social effect compares to the one found for immigrants. Columns (5) and (6) of Table 4 provides IV estimates of the effect of the employment rate of network members on the 36 month re-employment probability of a sample of native displaced workers. Controls include age and gender dummies for worker $i$ plus the averages of the same variables for network's members and a set of dummies for the size of the reference group. ${ }^{28}$ In column (5), only dummies for the month of displacement are added to the regressions.

The effect is positive and significant: a 10 percentage point increase in the employment rate of past co-workers increases re-employment probability of displaced native workers by about one percentage point. A higher employment rate of past co-workers is beneficial also for

\footnotetext{
${ }^{27}$ Table A3 in Appendix A provides supplementary robustness checks. I first run regressions in which I include a control for the industry of displacement: estimates of the social effect stay significant and positive when network members are co-workers from the same country of origin; not significant effects are found for other network members, both foreigners and natives. Moreover I run regressions in which I simultaneously include the network employment rate of co-national, non-national and native past co-workers: only the coefficient of network members from the same country of origin is positive and statistically significant.

${ }^{28}$ Country of origin dummies are included but automatically dropped in the regressions as all the displaced individuals are Italian workers and thus share the same nationality. Standard errors are thus clustered by the date of displacement.
} 
displaced native workers. When more restrictive controls are added to the regressions (column 6), the effect does not change in significance and it slightly increases in magnitude, being now the coefficient equal to 0.109. These results are in line with those by Cingano and Rosolia (2012): they found that ten percentage point increase in the network employment rate raises re-employment probability of displaced workers by 1.8 and percentage points.

From these results, we can draw two conclusions that are consistent with the empirical evidence of Figure 1. First, social interactions take place among Italian employees, suggesting that also native co-workers interact and help each other in job search. Second, immigrants rely more on the help of their acquaintances than natives: the size of the network employment rate coefficient for immigrants is higher the size of the one for natives, i.e. 0.57 versus 0.11 .

\section{Post-Displacement Outcomes: Mechanisms and Segregation}

\subsection{Mechanisms behind the Social Effect}

This last section attempts to shed light on the possible mechanisms behind the estimates of the social effect previously found. Among several possible explanations, a positive network effect can arise from two different channels: information and norms (Bertrand et al., 2000).

According to the information story (Calvo-Armengol and Jackson, 2004), the more people employed in the network, the higher the probability of finding a job as the arrival rate of job offers increases. If employed, network members are better informed about job vacancies in firms or municipalities in which they work; moreover, employed members are also more likely to share their sources of job information, such as previous or current employers, with unemployed members. Therefore the higher the employment rate of the network, the lower the competition within the network for job openings and thus the higher the arrival rate of offers for displaced migrants.

Similarly, social norms can lead to a positive network effect on re-employment probabilities: as more members of the network are employed, unemployment may turn into a social stigma hence pushing displaced workers to rapidly exit from unemployment. A high network employment rate then may act as a sort of peer pressure on displaced migrants.

Table 5 provides estimates of the of the network employment rate on different outcome variables such as the firm and the municipality in which displaced immigrants find job after firm closure. Investigating where displaced immigrants end up after the displacement episode helps us understanding the mechanism behind the social effect.

The first outcome variable looks at firms in which the pivotal worker is re-employed after his own displacement. Firms are divided into two groups: firms in which at least one member 
of the network, i.e. a co-national past co-worker, has ever worked before individual i's displacement episode, i.e. connected firms; and firms in which no past co-worker has ever been employed, i.e. non-connected firms. ${ }^{29}$

In column (1) of Table 5, the dependent variable is the probability of working in a connected firm; the coefficient is positive and significant at $10 \%$ level implying that a 10 percentage point increase in the network employment rate increases the chances of displaced workers of finding a job in connected firms by 5.4 percentage points. In column (2) the outcome variable is the probability of finding a job in non-connected firms: the coefficient is still positive but not significant and it is also smaller in magnitude than the one found in column (1). Note that these coefficients sum up to the net total effect found in column (3) of Table 3, i.e. 0.574. ${ }^{30}$

Past co-workers may also hear about job openings in municipalities in which they currently work or in which they have worked in the past; thus, they may help their unemployed network members by placing them in municipalities in which they have a connection. Regressions reported in Columns (3) and (4) of Table 5 look at the effect of the network employment rate on the municipality in which the displaced migrant is employed after job loss; in column (3) the dependent variable is the probability of working in a connected municipality, where at least one past co-worker has ever been employed. Results are strongly positive and significant at $1 \%$ level, the coefficient of the social spillovers predicts that a 10 percentage point increase in the network employment rate increases the probability of working in connected cities by 7.9 percentage points. Conversely, the estimate of the network employment rate on the probability of finding a job in a non-connected municipality is negative but not significant.

The last columns of Table 5 investigate the effect of past co-workers' employment status on the probability of working in industries in which displaced immigrants have a connection, i.e. in which at least one network member has worked in the past. Again, the effect is positive and significant: stronger networks will help unemployed immigrants to get a job in connected industries.

As the employment rate of the network raises, displaced migrants are more likely to work after job loss in firms, municipalities and industries in which past co-workers have a connection. These results are consistent with the information transmission story. Each network

\footnotetext{
${ }^{29}$ The econometric specification controls for the interaction of the country of origin, month of displacement and the first city of work. As in the previous section, the employment rate of network members is instrumented with displacement episodes experienced by group members before worker i's job loss. With respect to regressions in Table 3, only the dependent variable has changed therefore first stage regressions are the same as the ones reported in column (3) of Table 3.

${ }^{30}$ If a worker does not find a job within 36 months since job loss, both outcome variables, the probability of finding a job in connected and in non-connected firms, take a value equal to zero.
} 
has a pool of job information's sources, represented by connected workplaces; as more people in the network are employed, the higher the probability of hearing about job vacancies and the higher the probability that employed members will pass this information to the unemployed. ${ }^{31}$

Interpreting these results through the lenses of the social norm channel is more difficult; this story predicts that as the employment rate of network increases, immigrants will exit the unemployment faster. There is no implication about the place of work in which displaced migrants will find a job. In addition, the social norm theory is not consistent with the delayed effect of the social effect found in Figure 6.

\subsection{Networks and Segregation}

The last part of this work analyses whether networks push immigrants to cluster together in the same local labor markets. Previous results show that immigrants pass information to their unemployed network members about job vacancies in connected workplaces. This result may also suggest that as the network employment rate raises, so do the probability of being employed in firms in which other immigrants from the same country of origin are employed, eventually increasing the level of segregation.

To further explore this issue, Table 6 reports a set of regressions in which the dependent variable is the probability of finding a job in firms in which at least one migrant worker is employed. I then distinguish between workers from the same country of origin and workers of different foreign nationalities.

The first column reports results from a regression in which the dependent variable is the probability that a displaced migrant ends up working with at least one immigrant worker from the same country of origin in the 36 months after his own displacement episode. The coefficient is positive and significant: as the network employment rate increases by 10 percentage points, the probability of ending up working with at least one co-national increases by 7.7 percentage points. In column (2) I explore whether the network employment rate has any effect on the probability of finding a job in firms in which no immigrant from the same country is employed, the effect is negative but not statistically significant. ${ }^{32}$

This positive effect in column (1) may be due to the fact that immigrants are employed in firms that systematically hire foreign workers; column (3) then looks at the probability of finding a job in firms in which at least one immigrant of a different foreign nationality is employed; the effect of the network employment rate is positive but not significant; it is also

\footnotetext{
${ }^{31}$ Employed network members might act as referrals when passing information about job vacancies to their past co-workers (Dustmann et al., 2010).

${ }^{32}$ Note that the two coefficients sum up to the network effect found in column (3) of Table 3.
} 
smaller in magnitude than the coefficient in column (1). Column (4) finally reports the network employment rate coefficient on the probability of finding a job in a firm in which no immigrant is employed; this estimated coefficient is small and magnitude and not statistically significant.

Overall, this Table shows that a higher network employment rate increases the probability that displaced immigrants will be employed by firms in which other immigrants from the same country of origin work, ultimately increasing the level of segregation at the workplace.

\section{Concluding Remarks}

The aim of this work is to provide consistent estimates of the causal effect of past co-workers employment status on displaced immigrants' job search outcomes. Using matched employeremployee micro data from the administrative records of the Italian Social Security Administration (INPS), I show that an increase in the employment prospects of socially connected workers improves immigrants' job search outcomes.

To deal with several identification issues, I use displacement episodes of past co-workers as an instrument for their current employment status. As long as firm closures are uncorrelated with a worker's characteristics that affect both his and his network's labor market outcomes, this instrumental variable approach will lead to consistent estimates of the effect of interest. To further account for correlated effects, such as labor demand and supply shocks, controls for the time of displacement, the country of origin and the first municipality of work are included in the regressions.

The paper offers three key findings. First, the net effect of migrant networks on reemployment probabilities is positive: a 10 percentage point increase in the network employment rate raises the probability of finding employment within 36 months after job loss by 5.7 percentage points. The effect of past co-workers from the same country of origin is positive and significant in any specifications adopted. The social effect becomes negative and not significant when I consider as a reference group past co-workers from different countries; I take this last finding as a validation of the empirical strategy.

Second, the network effect is particularly relevant for immigrants with limited job offers in the labor market, such as low skilled and low tenured workers. Moreover, estimates show that the magnitude of the social effect increases after the 20th month of job search: immigrants at the bottom of the skills distribution are the ones who rely more on the help of their past coworkers.

Third, the analysis of post-displacement outcomes shows that employed network members provide displaced co-workers with information about job vacancies in cities and firms in 
which they have worked, i.e. connected workplaces. The information transmission mechanism described by Calvo-Armengol and Jackson (2004) seems to be the prevailing one: the higher the employment rate of the network, the lower the competition within the network for the same sources of job information.

This work also presents evidence of the positive correlation between the magnitude of the network effect and the level of immigrant workplace segregation. As the network employment rate increases, displaced migrant workers are more likely to find a job in firms in which at least one immigrant of the same nationality is employed, potentially increasing the level of exposure to co-workers from the same country of origin.

The evidence of a positive social effect suggests that interactions between employees coming from the same country of origin are an important channel through which migrants find a job. However, networks may eventually push immigrants to cluster into the same workplaces.

\section{References}

Anastasia, Bruno, Mario Gambuzza, and Maurizio Rasera. 2001. "Le sorti dei flussi: dimensioni della domanda di lavoro, modalita’ di ingresso e rischio disoccupazione dei lavoratori extracomunitari in Veneto." Osservatorio Veneto Working Paper.

Aslund, Olof and Oskar Nordström Skans. 2010. "Will I see you at work? Ethnic workplace segregation in Sweden 1985-2002." Industrial and Labor Relations Review, 63 (3): 471493.

Bandiera, Oriana, Iwan Barankay, and Imran Rasul. 2008. "Social capital in the workplace: Evidence on its formation and consequences." Labour Economics, 15(4): 724-748.

Bartelsman, Eric, Stefano Scarpetta, and Fabiano Schivardi. 2003. "Comparative analysis of firm demographics and survival: micro level evidence for the OECD countries." OECD Economic Department Working Paper, no. 348.

Beaman, Lori. 2012. "Social Networks and the Dynamics of Labor Market Outcomes: Evidence from Refugees Resettled in the U.S." Review of Economic Studies, 79(1): 128161.

Bertrand, Marianne, Erzo F. P. Luttmer, and Sendhil Mullainathan. 2000. "Network Effects And Welfare Cultures." Quarterly Journal of Economics, 115(3): 1019-1055.

Boeri, Tito, Marta De Philippis, Eleonora Patacchini, and Michele Pellizzari. 2011. "Moving to Segregation: Evidence from 8 Italian cities." IGIER Working Paper, 390. 
Calvo-Armengol, Antoni and Matthew O. Jackson. 2004. "The Effects of Social Networks on Employment and Inequality." American Economic Review, 94(3): 426-454.

Card, David. 2009. "Immigration and Inequality." American Economic Review, 99(2): 1-21.

Card, David, Francesco Devicienti, and Agata Maida. 2014. "Rent-Sharing, Hold-up, and Wages: Evidence from Matched Panel Data." Review of Economic Studies, 81(1): 84-111. Cingano, Federico and Alfonso Rosolia. 2012. "People I Know: Job Search and Social Networks." Journal of Labor Economics, 30(2): 291 - 332.

Cutler, David M., Edward L. Glaeser, and Jacob L. Vigdor. 1999. "The Rise and Decline of the American Ghetto." Journal of Political Economy, 107(3): 455-506.

Datcher Loury, Linda. 2006. "Some Contacts Are More Equal than Others: Informal Networks, Job Tenure, and Wages." Journal of Labor Economics, vol. 24(2): 299-318.

De Giorgi, Giacomo, Michele Pellizzari, and Silvia Redaelli. 2010. "Identification of Social Interactions through Partially Overlapping Peer Groups." American Economic Journal: Applied Economics, 2(2): 241-75.

Dustmann, Christian, Albrecht Glitz, and Uta Schoenberg. 2010. "Referral-Based Job Search Networks." IZA Discussion Paper, 5777.

Edin, Per-Anders, Peter Fredriksson, and Olof Aslund. 2003. "Ethnic Enclaves and the Economic Success of Immigrants: Evidence from A Natural Experiment." Quarterly Journal of Economics, 118(1): 329-357.

Fasani, Francesco. 2010. "Deporting Undocumented Immigrants: the Role of labor Demand Shocks." Mimeo.

Gibbons, Robert and Lawrence F. Katz. 1992. "Does Unmeasured Ability Explain Interindustry Wage Differentials?" Review of Economic Studies, 59(3): 515-535.

Glitz, Albrecht. 2013. "Coworker Networks in the Labor Market." IZA Discussion Papers, 7392.

Goel, Deepti and Kevin Lang. 2010. "Social Ties and the Job Search of Recent Immigrants." NBER Working Papers, 15186.

Hensvik, Lena and Oskar Nordström Skans. 2014. “Social Networks, Employee Selection and Labor Market Outcomes” Journal of Labor Economics, forthcoming.

Ioannides, Yannis M. and Linda Datcher Loury. 2004. "Job Information Networks, Neighborhood Effects, and Inequality." Journal of Economic Literature, 42: 1056-1093.

Kramarz, Francis and Oskar Nordström Skans. 2014. "When strong ties are strong: Family networks and youth labor market entry.” Review of Economic Studies, 81(3): 1164-1200. 
Lazear, Edward P. 1999. "Culture and Language." Journal of Political Economy, 107(S6): S95-S126.

Manski, Charles F. 1993. "Identification of Endogenous Social Effects: The Reflection Problem." Review of Economic Studies, 60(3): 531-542.

Marmaros, David and Bruce Sacerdote. 2006. "How Do Friendships Form? " Quarterly Journal of Economics, 121(1): 79-119.

Massey, Douglas and Nancy Denton. 1988. "The Dimensions of Residential Segregation." Social Forces, 67: 281-315.

Ministero dell’Interno, 2007. "Primo Rapporto sugli Immigrati in Italia."

Moffitt, Robert A. 2001. "Policy Interventions, Low-Level Equilibria, and Social Interactions." In Social Dynamics, ed. Steven N. Durlauf and H. Peyton Young, 45-82. Cambridge, MA: MIT Press.

Montgomery, James D. 1991. "Social Networks and Labor Market Outcomes: Towards an Economic Analysis." American Economic Review, 81(5): 1408-1418.

Munshi, Kaivan. 2003. "Networks In The Modern Economy: Mexican Migrants in the U.S. Labor Market." Quarterly Journal of Economics, 118(2): 549-599.

Patel, Krishna and Francis Vella. 2013. "Immigrant Networks and Their Implications for Occupational Choice and Wages.” Review of Economics and Statistics, 95(4): 1249-1277.

Pellizzari, Michele. 2010. "Do friends and relatives really help in getting a good job? " Industrial and Labor Relations Review, 63(3): 494-510.

Soetevent, Adriaan R. 2006. "Empirics of the Identification of Social Interactions; an Evaluation of the Approaches and Their Results." Journal of Economic Surveys, 20(2): 193-228.

Tattara, Giuseppe and Bruno Anastasia. 2003. "How was that the Veneto region became so rich? Time and causes of a recent success." MPRA Paper 18458.

Venturini, Alessandra and Claudia Villosio. 2008. "labor-market assimilation of foreign workers in Italy." Oxford Review of Economic Policy, 24(3): 518-542.

von Wachter, Till, and Stefan Bender. 2007. "Do initial conditions persist between firms? An analysis of firm-entry cohort effects and job losers using matched employer-employee data." IAB Discussion Paper 200719. 


\section{Figures and Tables}

\section{Figure 1: Share of employees who found their current job through personal contacts}

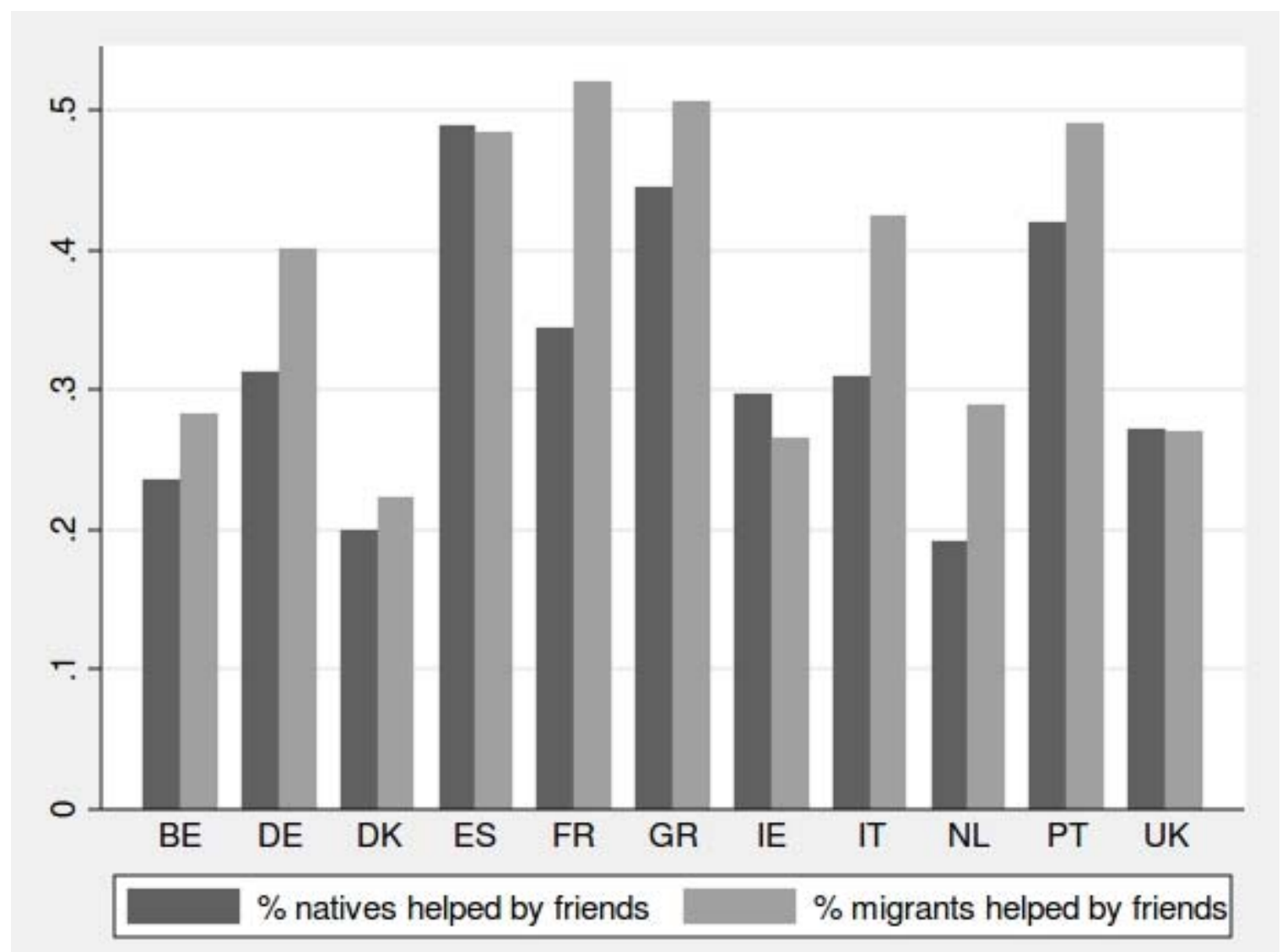

Notes: author's calculations on ECHP data for the period 1994-2001. The sample includes private sector dependent employees aged 16-64; Luxembourg, Sweden, Finland, Austria and Denmark are excluded from the analysis as they are not covered in all the waves. The precise question asked in this survey is: "by what means were you first informed about your current job?". Respondents then have six different alternatives, which include friends, family or personal contacts". 
Figure 2: Share of migrant workers in Veneto, 1975 - 2001

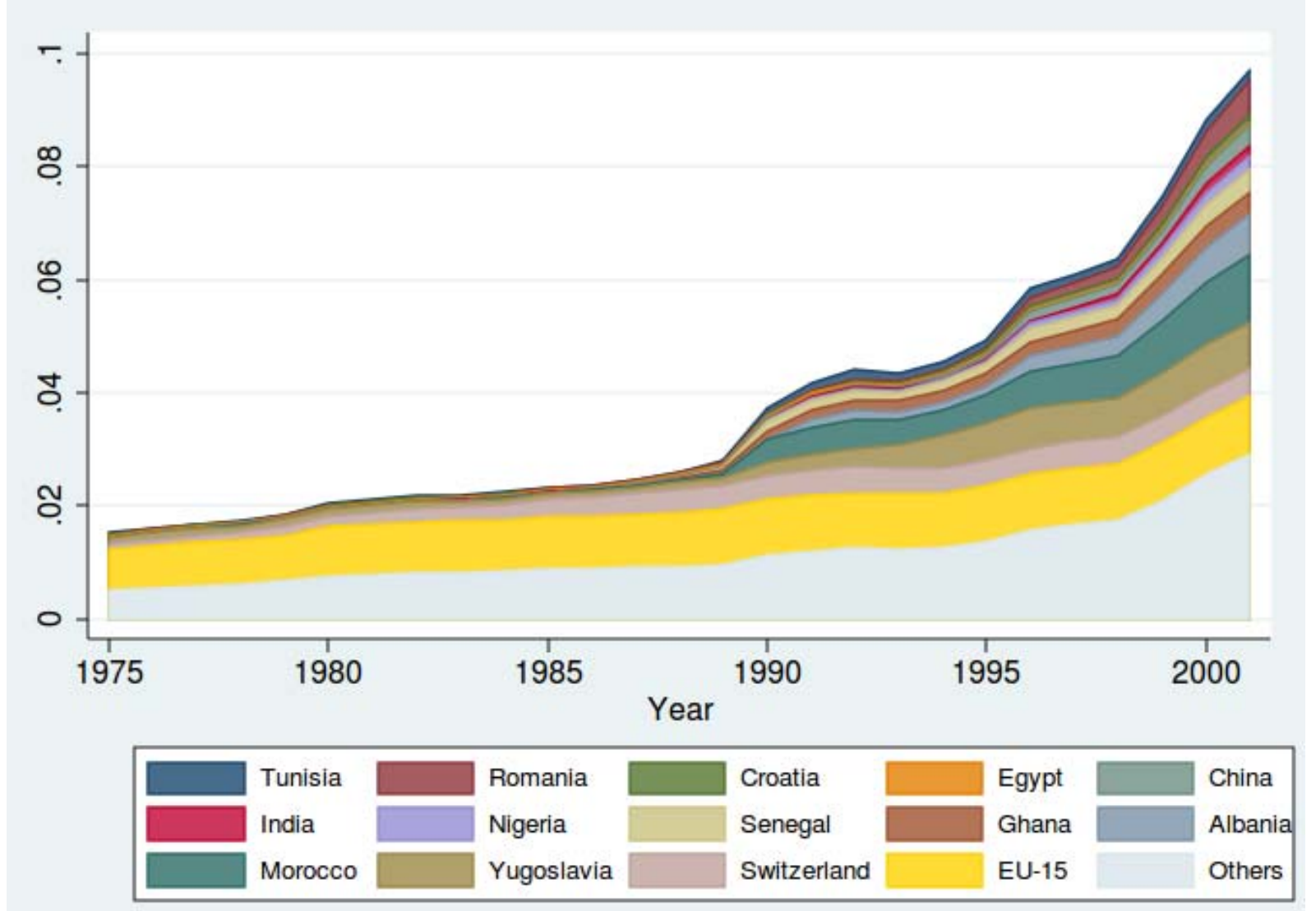

Notes: author's calculations on INPS data for the period 1975 - 2001. Each shaded area represents the share of immigrants from the corresponding country of origin on the overall population. 
Figure 3: Duncan index of segregation at municipality of work level

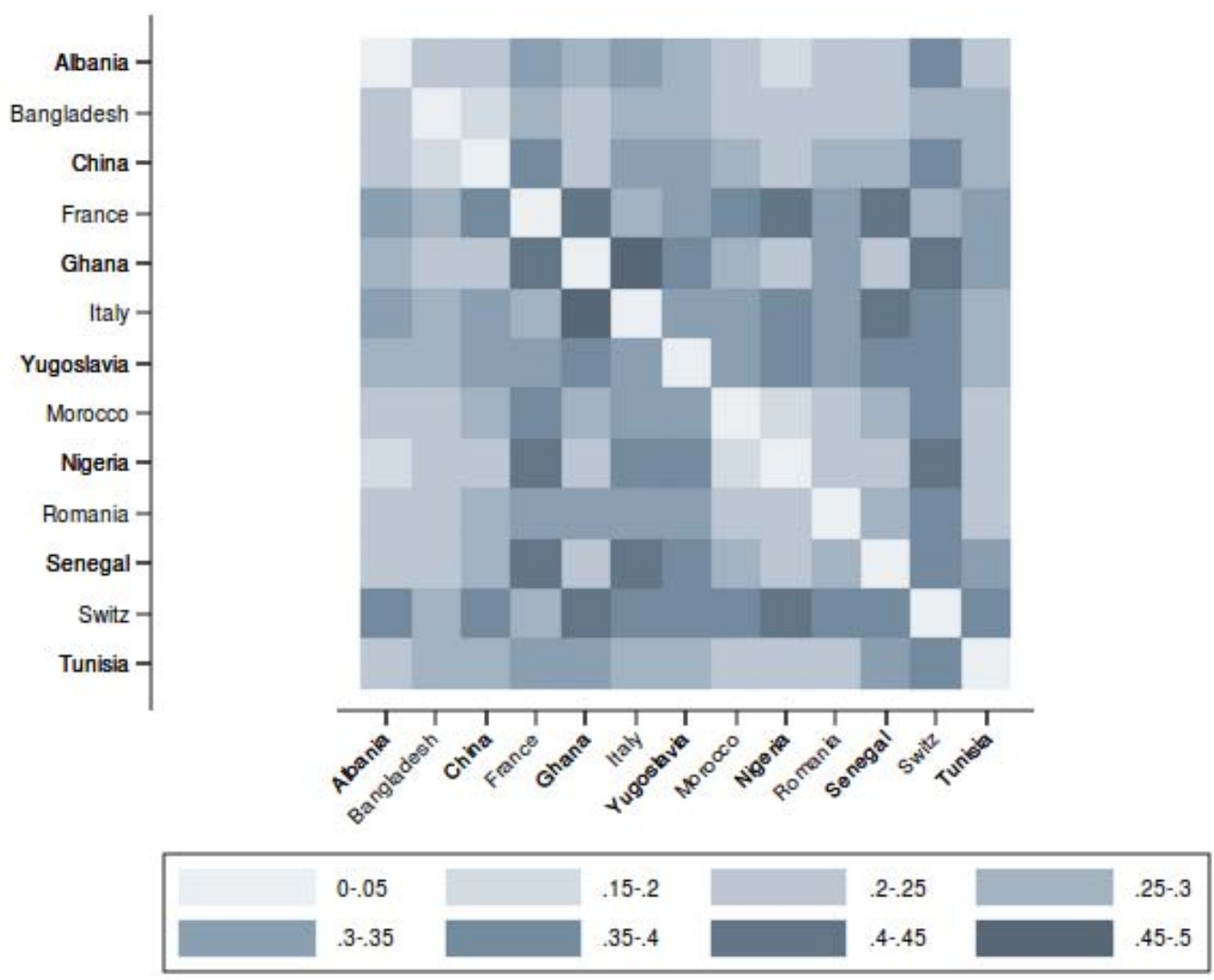

Notes: this Figure is based on INPS data for the period 1975-2001. Each square in the heat map represents the value of the dissimilarity index of each country of origin from anyone other. 
Figure 4: The effect of displacements on employment probabilities

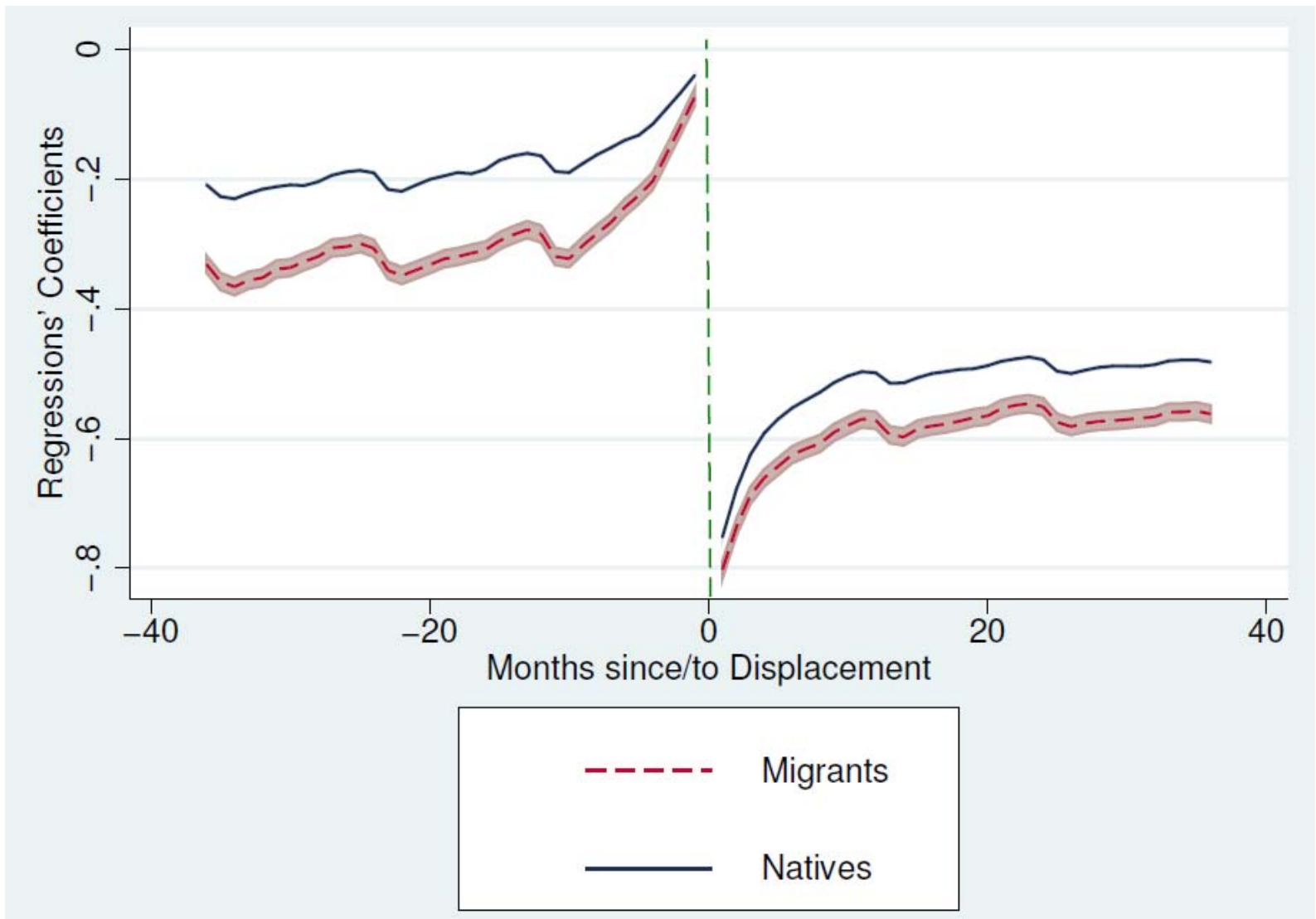

Notes: the sample includes displaced workers only. Two separate sets of regressions have been run for migrants and natives The estimated equation is $y_{i t s}=\alpha+\sum_{k=-36}^{+36} \delta_{k} D_{i k}+\lambda_{i}+\varepsilon_{i t s}$. $D_{i k}$ are dummies for a worker's time exposure for each month $t$ before and after displacement, i.e. $\boldsymbol{D}_{\boldsymbol{i} \boldsymbol{k}}=\mathrm{I}[\mathrm{t}-\mathrm{s}>\mathrm{k}]$, where $s$ is the displacement date. All regressions include individual fixed effects, standard errors are robust. The shaded areas in the figure represent the $95 \%$ level confidence intervals. 
Figure 5: Re-employment probabilities by month (up to 36 months)

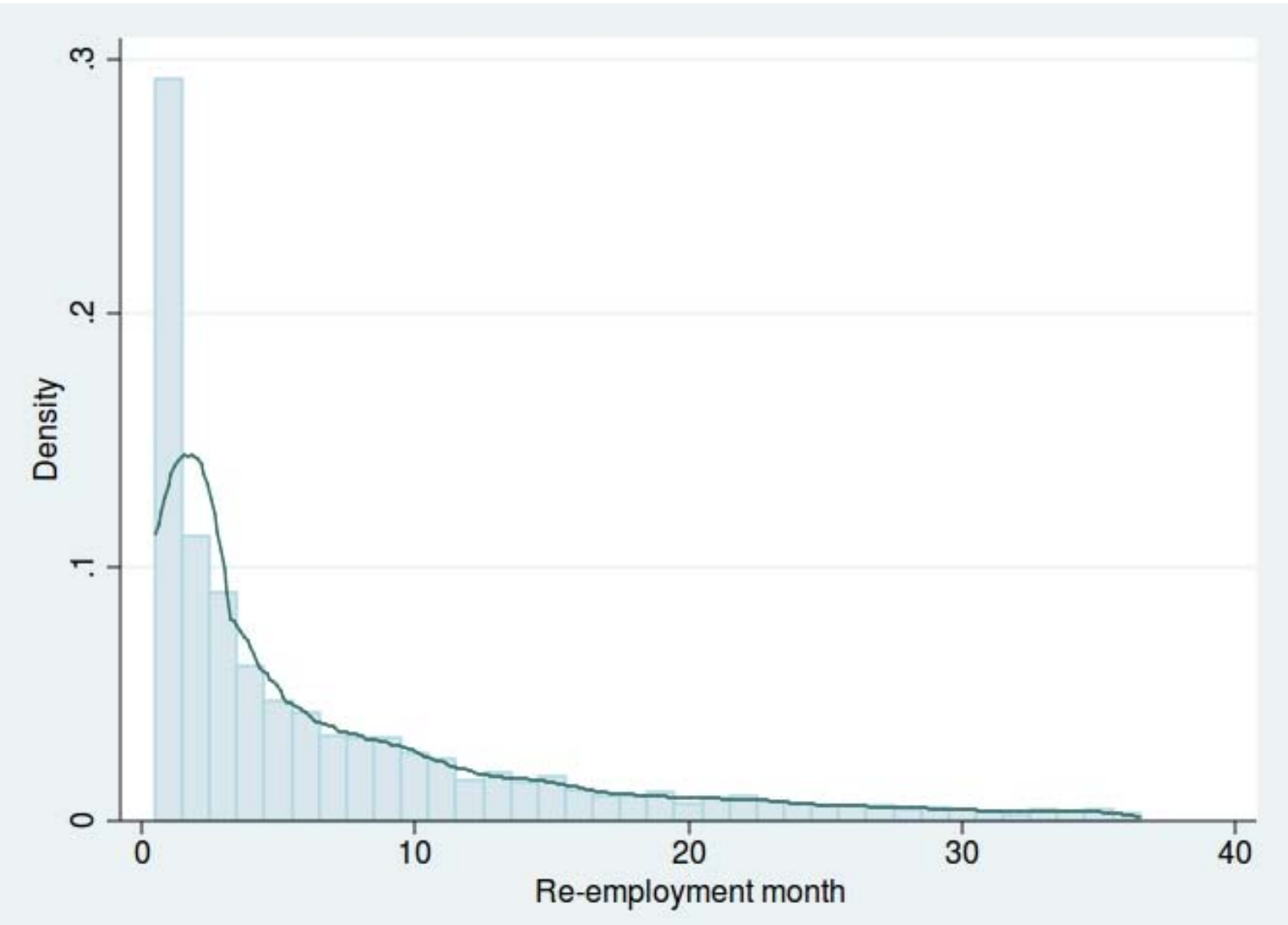

Notes: author's calculations on INPS data for the period 1980- 2001. Closures occurred after December 1998 and before January 1980 are excluded from the analysis. The percentage of individuals censored is about $27 \%$. The blue line plots the Kernel density function. 
Figure 6: Timing of the social effect

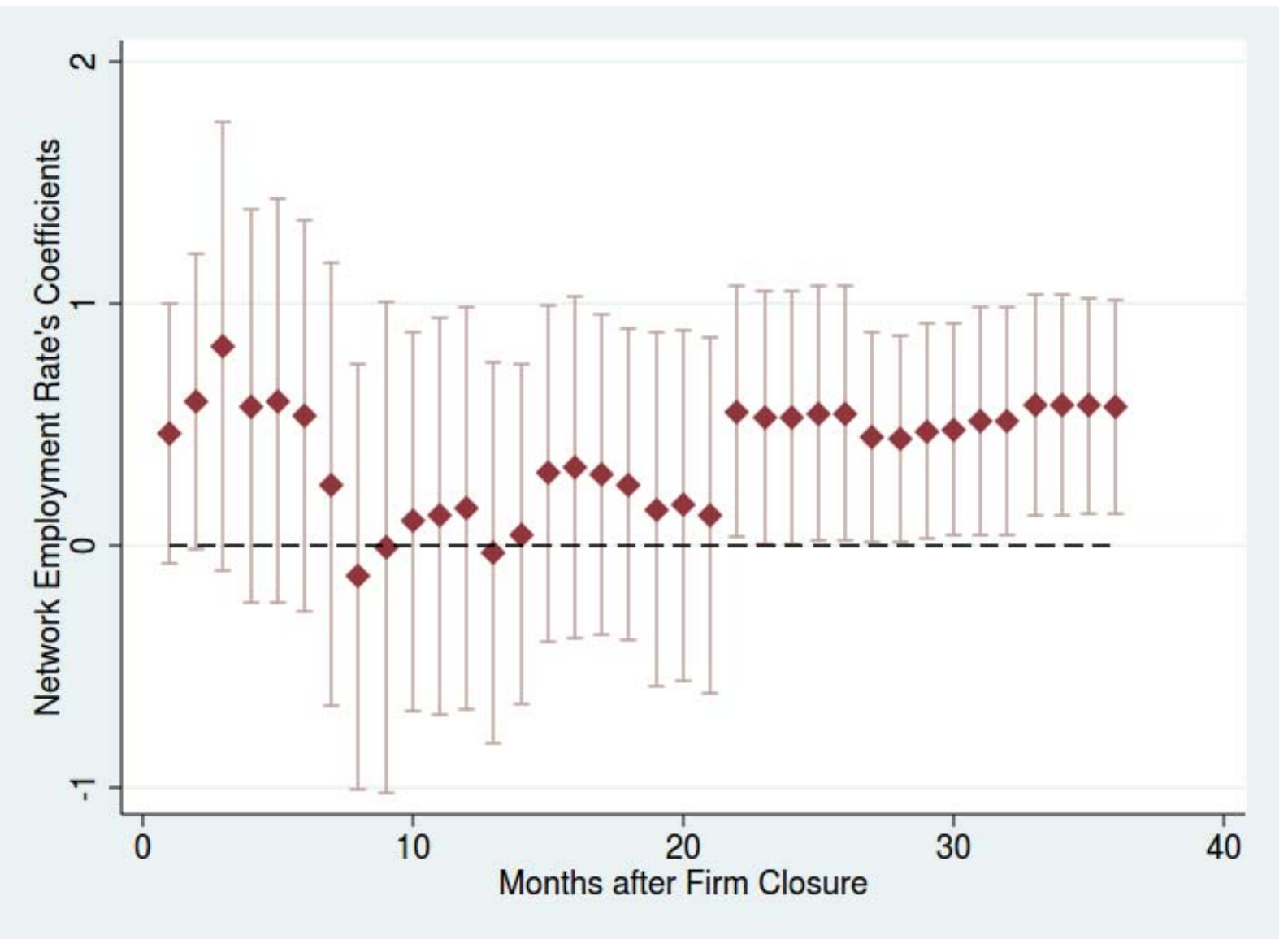

Notes: the coefficients are estimated using equations (1) and (2), where the dependent variable is the probability of finding a job by each of the 36 months following job loss. Standard errors are clustered by country of origin; controls include age and gender dummies, nationality, time of displacement and the interaction between the first city of work, nationality and time of displacement. The vertical bars in the figure represent the $90 \%$ level confidence intervals. 
Table 1: Descriptive statistics

\begin{tabular}{lrrr}
\hline \hline & Total & Natives & Migrants \\
Panel a: All workers & & & \\
\hline Number of individual workers & $3,604,399$ & $3,339,177$ & 265,222 \\
Number of job matches & $12,561,479$ & $11,711,885$ & 849,594 \\
\% Workers in the last year of the dataset (2001) & 45.53 & 44.53 & 58.15 \\
Duration of employment spells (months) & 31.16 & 32.24 & 16.21 \\
\% Male & 59.11 & 58.55 & 66.17 \\
Age & 33.40 & 33.46 & 32.06 \\
Gross weekly wage (2003 euros) & 683.04 & 684.27 & 655.76 \\
Number of co-workers ever worked with & 461.07 & 480.77 & 213.04 \\
Number of migrant co-workers ever worked with & 13.72 & 12.75 & 25.93 \\
Occupation: & & & \\
\% Blue collars & 63.16 & 62.84 & 71.71 \\
\% White collars & 29.92 & 30.19 & 22.71 \\
\% Managers & 1.25 & 1.25 & 1.08 \\
Transitions (monthly rates): & & & \\
Exit rate from employment & 1.7 & 1.65 & 3.2 \\
Entry rate into employment & 1.68 & 1.62 & 3.14 \\
& & & \\
Panel b: Displaced workers & & & \\
Number of displacement episodes & 403,368 & 385,101 & 18,267 \\
Number of workers ever displaced & 354,073 & 337,216 & 16,857 \\
\% Workers displaced every month & 0.10 & 0.10 & 0.14 \\
Characteristics at time of displacement: & & & \\
\% Male & 51.08 & 50.66 & 59.88 \\
Age & 30.89 & 30.88 & 30.99 \\
\% Blue collars & 67.16 & 66.82 & 74.28 \\
\% White collars & 19.81 & 19.92 & 17.55 \\
\% Managers & 0.27 & 0.27 & 0.29 \\
Gross weekly wage (2003 euros) & 543.95 & 545.36 & 514.26 \\
Probability of having a job after 3 months & 49.05 & 49.17 & 46.21 \\
Probability of having a job in 4 to 9 months & 13.21 & 13.17 & 14.15 \\
Probability of not having a job after 9 months & 28.95 & 28.9 & 29.97 \\
\hline Nor & $15 P 5$ & \\
\hline
\end{tabular}

Notes: the table reports averages for the period 1975-2001 based on INPS data. Displaced workers' characteristics refer to the values at the time of displacement. 
Table 2: Firms' and municipalities' characteristics

Firms:

Number of firms

$1,121,748$

Firm Size

6.87

$\%$ Migrant workers

4.26

$\%$ Firms in the first year of the dataset (1975)

14.15

\% Firms in the last year of the dataset (2001)

Months in the dataset

142.16

\% Firms ever closed

16.32

\% Firms closed every month

1.16

Closed firms’ size

4.81

Duncan index by migrant status (Firm Level)

0.63

Isolation index by migrant status (Firm Level)

0.27

Municipalities:

Number of Municipalities

Municipality working population

218.14

Share of Migrants

4.79

Duncan index by migrant status (Municipality Level)

0.25

Isolation index by migrant status (Municipality Level)

0.03

Notes: The table reports summary statistics for the period 1975-2001 based on INPS data. Values for the Duncan and the Isolation indexes are averages. 
Table 3: Probability of re-employment and the network effect - IV Regressions

\begin{tabular}{|c|c|c|c|c|c|c|c|c|c|}
\hline & \multicolumn{3}{|c|}{ All workers } & \multicolumn{2}{|c|}{ Occupation } & \multicolumn{2}{|l|}{ Tenure } & \multicolumn{2}{|c|}{ "Country of Origin } \\
\hline & & & & $\begin{array}{c}\text { Blue } \\
\text { collars }\end{array}$ & Others & Low & High & $\begin{array}{c}\text { non- } \\
\text { OECD }\end{array}$ & OECD \\
\hline & (1) & (2) & (3) & (4) & (5) & (6) & (7) & (8) & (9) \\
\hline Network Employment Rate & $\begin{array}{c}0.407 * * * \\
(0.134)\end{array}$ & $\begin{array}{c}0.318 * \\
(0.168)\end{array}$ & $\begin{array}{c}0.574 * * \\
(0.266)\end{array}$ & $\begin{array}{c}0.543 * * \\
(0.267)\end{array}$ & $\begin{array}{c}0.283 \\
(1.789)\end{array}$ & $\begin{array}{c}0.899 * * \\
(0.433)\end{array}$ & $\begin{array}{c}0.258 \\
(1.463)\end{array}$ & $\begin{array}{c}0.587 * * \\
(0.253)\end{array}$ & $\begin{array}{c}2.551 \\
(4.100)\end{array}$ \\
\hline \multicolumn{10}{|l|}{ First Stage Regressions: } \\
\hline Network Displacement Rate & $\begin{array}{c}0.321^{* * *} \\
(0.045)\end{array}$ & $\begin{array}{c}0.278 * * * \\
(0.043)\end{array}$ & $\begin{array}{c}0.533^{* * *} \\
(0.125)\end{array}$ & $\begin{array}{c}0.549 * * * \\
(0.120)\end{array}$ & $\begin{array}{c}0.551 \\
(0.691)\end{array}$ & $\begin{array}{c}0.714^{* * *} \\
(0.181)\end{array}$ & $\begin{array}{c}0.159 \\
(0.158)\end{array}$ & $\begin{array}{c}0.535^{* * *} \\
(0.131)\end{array}$ & $\begin{array}{c}0.139 \\
(0.352)\end{array}$ \\
\hline F-Test & 51.35 & 40.74 & 18.05 & 42.49 & 0.63 & 15.59 & 1.02 & 16.60 & 0.16 \\
\hline \multicolumn{10}{|l|}{ Controls: } \\
\hline$\overline{\text { Age and }}$ Gender Dummies & Yes & Yes & Yes & Yes & Yes & Yes & Yes & Yes & Yes \\
\hline Network Size Dummies & Yes & Yes & Yes & Yes & Yes & Yes & Yes & Yes & Yes \\
\hline Time & Yes & Yes & Yes & Yes & Yes & Yes & Yes & Yes & Yes \\
\hline Nationality*Time & No & Yes & Yes & Yes & Yes & Yes & Yes & Yes & Yes \\
\hline Nationality*Time*Municipality & No & No & Yes & Yes & Yes & Yes & Yes & Yes & Yes \\
\hline Observations & 10,738 & 10,738 & 10,738 & 7,635 & 3,103 & 5,457 & 5,281 & 6,285 & 4,453 \\
\hline
\end{tabular}

Notes: * $\mathrm{p}<0.10, * * \mathrm{p}<0.05, * * * \mathrm{p}<0.01$; standard errors in brackets are clustered by country of origin; age dummies are defined as: 15-24, 25-34, 35-44, 45-54, 55-64, 65+. Network Size dummies are defined as: 0, 1-5, 6-15, 16-49, 50+. The dependent variable takes value one if the pivotal worker has ever been employed in the first 36 months after displacement. The instrumental variable is the share of network members displaced before the pivotal worker's displacement episode. Low-Tenure is a dummy variable that is equal to one if the pivotal worker has a number of months in employment below the median, i.e. 20 months. OECD is a dummy indicating workers whose country of origin was a member of the OECD as of 2001, i.e. Australia, Austria, Belgium, Canada, Czech Republic Denmark, Finland, France, Germany, Greece, Hungary, Iceland, Ireland, Italy, Japan, Korea Luxembourg, Mexico, Netherlands, New Zealand, Norway, Poland, Portugal, Slovak Republic, Spain, Sweden, Switzerland, Turkey, United Kingdom, United States. 
Table 4: Probability of re-employment and the network effect- Effects of other groups

\begin{tabular}{|c|c|c|c|c|c|c|}
\hline & \multicolumn{4}{|c|}{ "Displaced Immigrants’ Re-employment Probability } & \multirow{2}{*}{\multicolumn{2}{|c|}{$\begin{array}{c}\text { Displaced Natives' Re-employment Probability } \\
\text { Network: Italians }\end{array}$}} \\
\hline & \multicolumn{2}{|c|}{ Network: Other Countries } & \multicolumn{2}{|c|}{ Network: Italians } & & \\
\hline & (1) & $(2)$ & (3) & (4) & (5) & (6) \\
\hline Network Employment Rate & 0.048 & -0.127 & 0.032 & -0.089 & $0.095^{* *}$ & $0.109 * *$ \\
\hline & $(0.129)$ & $(0.282)$ & $(0.062)$ & $(0.098)$ & $(0.039)$ & $(0.045)$ \\
\hline \multicolumn{7}{|l|}{ First Stage Regressions: } \\
\hline \multirow[t]{2}{*}{ Network Displacement Rate } & $0.307 * * *$ & $0.474 * *$ & $0.577 * * *$ & $0.645 * * *$ & $0.292 * * *$ & $0.255^{* * *}$ \\
\hline & $(0.048)$ & $(0.181)$ & $(0.017)$ & $(0.092)$ & $(0.009)$ & $(0.009)$ \\
\hline F-Test & 40.08 & 6.83 & 1147.56 & 49.56 & 988.36 & 906.56 \\
\hline \multicolumn{7}{|l|}{ Controls: } \\
\hline Age and Gender Dummies & Yes & Yes & Yes & Yes & Yes & Yes \\
\hline Network Size Dummies & Yes & Yes & Yes & Yes & Yes & Yes \\
\hline Nationality*Time & Yes & Yes & Yes & Yes & Yes & Yes \\
\hline Nationality*Time*Municipality & No & Yes & No & Yes & No & Yes \\
\hline Observations & 10,738 & 10,738 & 10,738 & 10,738 & 223,936 & 223,936 \\
\hline
\end{tabular}

Notes: $* \mathrm{p}<0.10, * * \mathrm{p}<0.05, * * * \mathrm{p}<0.01$; standard errors in brackets are clustered by country of origin; age dummies are defined as: 15-24, 25-34, 35-44, 45-54, 55-64,

$65+$. Network Size dummies are defined as: 0, 1-5, 6-15, 16-49, 50+. The dependent variable takes value one if the pivotal worker has ever been employed in the first 36 months after displacement. The instrumental variable is the share of network members displaced before the pivotal worker's displacement episode. In columns (1) and (2) networks members are past co-workers from other foreign countries of origin; in columns (3) and (4) the reference group is composed of Italian past co-workers.

Columns (5) and (6) analyze a sample of Italian displaced workers, networks are composed of Italian past co-workers only; for this reason country of origin dummies are automatically dropped in the regressions; standard errors are thus clustered by the date of displacement. 
Table 5: Post displacement outcomes

\begin{tabular}{|c|c|c|c|c|c|c|}
\hline & \multicolumn{2}{|c|}{ Firms } & \multicolumn{2}{|c|}{ Municipalities } & \multicolumn{2}{|c|}{ Industries } \\
\hline & Connected & Non-connected & Connected & Non-connected & Connected & Non-connect \\
\hline & (1) & (2) & (3) & (4) & (5) & (6) \\
\hline Network Employment Rate & $\begin{array}{l}0.508^{*} \\
(0.275)\end{array}$ & $\begin{array}{c}0.066 \\
(0.344)\end{array}$ & $\begin{array}{c}0.789 * * * \\
(0.196)\end{array}$ & $\begin{array}{l}-0.216 \\
(0.251)\end{array}$ & $\begin{array}{l}0.819 * \\
(0.432)\end{array}$ & $\begin{array}{l}-0.246 \\
(0.260)\end{array}$ \\
\hline F-Test & 18.05 & 18.05 & 18.05 & 18.05 & 18.05 & 18.05 \\
\hline Controls: & & & & & & \\
\hline Age and Gender Dummies & Yes & Yes & Yes & Yes & Yes & Yes \\
\hline Network Size Dummies & Yes & Yes & Yes & Yes & Yes & Yes \\
\hline Nationality*Time*Municipality & Yes & Yes & Yes & Yes & Yes & Yes \\
\hline Observations & 10,738 & 10,738 & 10,738 & 10,738 & 10,738 & 10,738 \\
\hline
\end{tabular}

Notes: ${ }^{*} \mathrm{p}<0.10,{ }^{* *} \mathrm{p}<0.05,{ }^{* * *} \mathrm{p}<0.01$; standard errors in brackets are clustered by country of origin; age dummies are defined as: $15-24,25-34,35-44,45-54,55-64$, 65+. Network Size dummies are defined as: 0, 1-5, 6-15, 16-49, 50+. The instrumental variable is the share of network members displaced before the pivotal worker's displacement episode In columns (1), (3), and (5) the dependent variable is a dummy equal to one if the displaced worker finds a job (within 36 months following job loss) in Firms/Municipalities/Industries in which at least one past co-worker from the same country of origin has worked before the pivotal individual's displacement episode. In columns (2), (4), and (6) the dependent variable is a dummy equal to one if the displaced worker is employed in Firms/Municipalities/Industries in which no past co-worker from the same country of origin has ever worked. 
Table 6: Network effect and segregation

\begin{tabular}{lcccc}
\hline \hline & \multicolumn{3}{c}{ Probability of working in 36 months after iob loss with } \\
& Co-national & No co-national & Non-national & No non-national \\
\hline \multirow{2}{*}{ Network Employment Rate } & $(1)$ & $(2)$ & $(3)$ & $(4)$ \\
& $0.779^{*}$ & -0.205 & 0.540 & 0.034 \\
& $(0.483)$ & $(0.393)$ & $(0.393)$ & $(0.379)$ \\
F-Test & & & & \\
& 18.05 & 18.05 & 18.05 & 18.05 \\
Controls: & & & & \\
Age and Gender dummies & Yes & Yes & Yes & Yes \\
Network Size Dummies & Yes & Yes & Yes & Yes \\
Nationality*Time*Municipality & Yes & Yes & Yes & Yes \\
Observations & 10,738 & 10,738 & 10,738 & 10,738 \\
\hline \hline
\end{tabular}

Notes: ${ }^{*} \mathrm{p}<0.10, * * \mathrm{p}<0.05, * * * \mathrm{p}<0.01$; standard errors in brackets are clustered by country; age dummies are defined as: 15-24, 25-34, 35-44, 45-54, 55-64, 65+. Network Size dummies are defined as: 0, 1-5, 6-15, 16-49, $50+$; the instrumental variable is the share of network members displaced before the pivotal worker's displacement episode. The dependent variables are: column (1), the probability of meeting at least one co-worker (new or past) from the same country of origin in the 36 months after the displacement. Column (2), the probability of not meeting any co-worker from the same country of origin. Column (3), the probability of working with at least one co-worker of other foreign nationality, either past or new co-worker. Column (4), the probability of not meeting any co-workers from a different foreign country of origin. 


\section{Appendix A: Supplementary Figures and Tables}

Fig. A.1: Re-employment probabilities by month (up to 36 months) and tenure

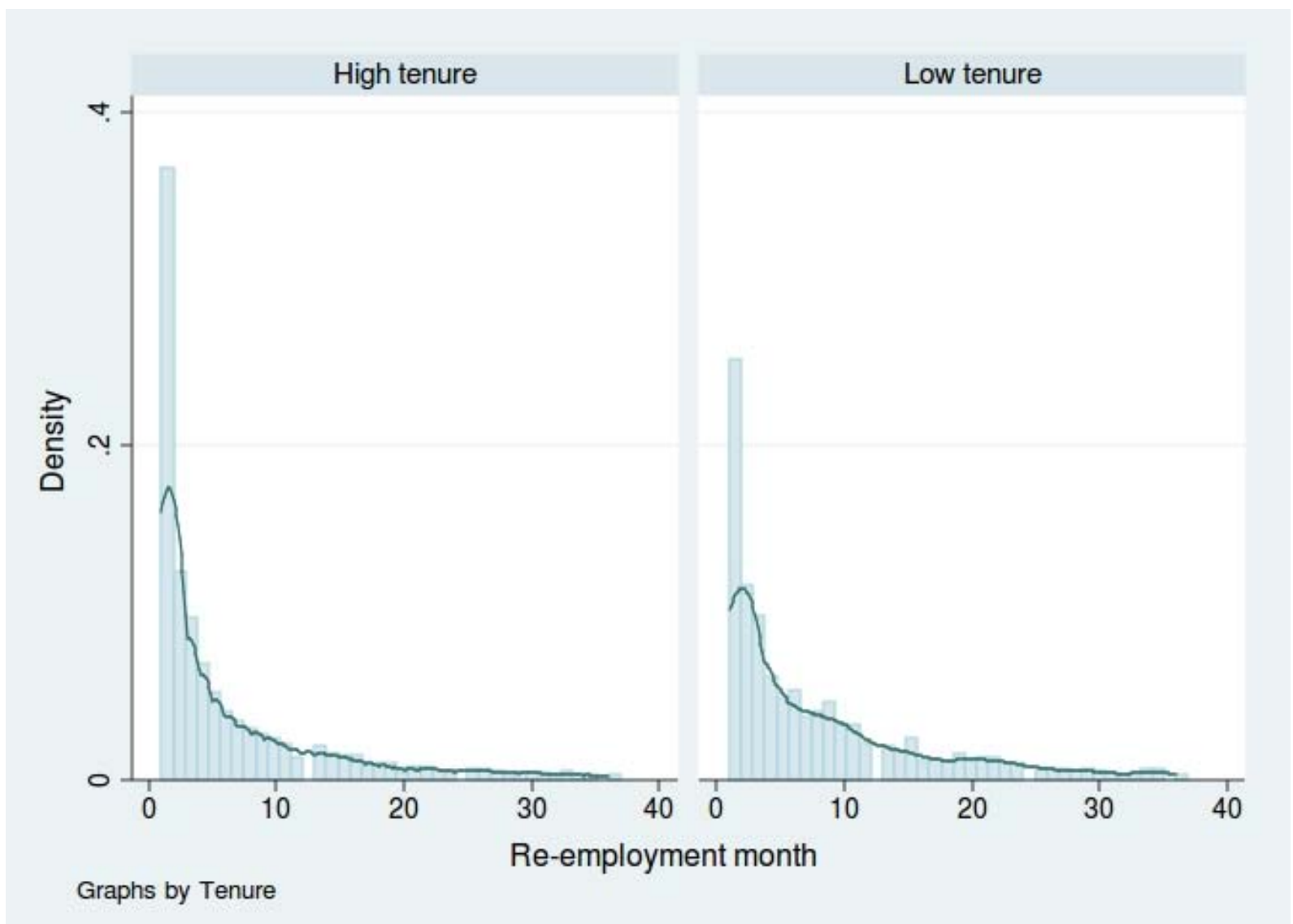

Notes: author's calculations on INPS data for the period 1980- 2001. Closures occurring after December 1998 and before January 1980 are excluded from the analysis. The percentage of the sample individuals censored is about $27 \%$. The blue line plots the Kernel density function. A worker is defined as low tenured if he has a number of months in employment below the median. 
Table A.1: Networks' characteristics

\begin{tabular}{lcccc}
\hline \hline Panel a: Displaced immigrants & Mean & Std. Dev. & Min. & Max. \\
$\begin{array}{l}\text { Re-employment within 36 months } \\
\text { Network's Size: }\end{array}$ & 0.669 & 0.470 & 0 & 1 \\
\hline Same Country & 10.104 & 37.189 & 0 & 228 \\
Other Foreign Countries & 5.733 & 18.098 & 0 & 304 \\
Natives & 13.967 & 56.716 & 0 & 823 \\
Network Employment Rate: & & & & \\
Same Country & 0.124 & 0.277 & 0 & 1 \\
Other Foreign Countries & 0.207 & 0.329 & 0 & 1 \\
Natives & 0.209 & 0.291 & 0 & 1 \\
Network Displacement Rate: & & & & 1 \\
Same Country & 0.017 & 0.101 & 0 & 1 \\
Other Foreign Countries & 0.032 & 0.131 & 0 & 1 \\
Natives & 0.112 & 0.213 & 0 & 1 \\
Panel b: Displaced natives & & & & 15,772 \\
Re-employment within 36 months & 0.709 & 0.454 & 0 & 1 \\
Network's Size: & 107.413 & 442.496 & 0 & 1 \\
Network Employment Rate: & 0.380 & 0.285 & 0 & 0 \\
Network Displacement Rate: & 0.091 & 0.138 & 0 & \\
\hline \hline
\end{tabular}

Notes: Panel A reports networks' characteristics for a displaced immigrant at time of displacement. Each displaced immigrants has three different types of past co-workers (i.e. networks): same country of origin, different foreign countries, and Italians. Networks of natives are only composed of Italian past co-workers, before job loss. 
Table A.2: OLS regressions

\section{Network: Same Country of Origin}

(1)

$\begin{array}{ccc}0.205^{* * *} & 0.138 * * * & 0.115 \\ (0.024) & (0.032) & (0.298)\end{array}$

(4)

Network Employment Rate

$\begin{array}{cccc}\text { Yes } & \text { Yes } & \text { Yes } & \text { Yes } \\ \text { Yes } & \text { Yes } & \text { Yes } & \text { Yes } \\ \text { Yes } & \text { Yes } & \text { Yes } & \text { Yes } \\ \text { No } & \text { Yes } & \text { Yes } & \text { Yes } \\ \text { No } & \text { No } & \text { Yes } & \text { Yes } \\ \text { No } & \text { No } & \text { No } & \text { Yes } \\ 10,738 & 10,738 & 10,738 & 10,738\end{array}$

Controls:

Age and Gender Dummies

Network Size Dummies

Time

Nationality*Time

Nationality*Time*Municipality

Nationality*Time*Municipality*Industry

10,738

10,738

10,738

10,738

Notes: $* \mathrm{p}<0.10,{ }^{* *} \mathrm{p}<0.05, * * * \mathrm{p}<0.01$; standard errors in brackets are clustered by country of origin; age dummies are defined as: 15-24, 25-34, 35-44, 45-54, 55-64, 65+. Network Size dummies are defined as: 0, 1-5, $6-15,16-49,50+$. The dependent variable takes value one if the pivotal worker has ever been employed in the first 36 months after displacement. Networks are composed past co-workers from the same country of origin.

Table A.3: Robustness checks: IV regressions
(1)
(2)
(3)
(4)

Network Employment Rate:

$\begin{array}{lll}0.586^{* *} & 0.312^{*} \\ \text { Same Country of Origin } & (0.281) & (0.178)\end{array}$

Other Foreign Countries

Natives

$-0.366$

Controls:

Age and Gender Dummies

Network Size Dummies

$\begin{array}{cccc}\text { Yes } & \text { Yes } & \text { Yes } & \text { Yes } \\ \text { Yes } & \text { Yes } & \text { Yes } & \text { Yes } \\ \text { Yes } & \text { Yes } & \text { Yes } & \text { Yes } \\ \text { Yes } & \text { Yes } & \text { Yes } & \text { Yes } \\ \text { Yes } & \text { Yes } & \text { Yes } & \text { Yes } \\ \text { No } & \text { Yes } & \text { Yes } & \text { Yes } \\ 10,738 & 10,738 & 10,738 & 10,738\end{array}$

Time

Nationality*Time

Nationality*Time*Municipality

Nationality*Time*Municipality*Industry

$10,738 \quad 10,738$

10,738

10,738

Notes: ${ }^{*} \mathrm{p}<0.10,{ }^{* *} \mathrm{p}<0.05,{ }^{* * *} \mathrm{p}<0.01$; standard errors in brackets are clustered by country of origin; age dummies are defined as: 15-24, 25-34, 35-44, 45-54, 55-64, 65+. Network Size dummies are defined as: 0, 1-5, $6-15,16-49,50+$. The dependent variable takes value one if the pivotal worker has ever been employed in the first 36 months after displacement; the instrumental variable is the share of network members displaced before the pivotal worker's displacement episode. 


\section{Appendix B: Immigration Policies in Italy}

Between 1970 and 1980 Italy changed from being an emigration country into an immigration country; in 1985 the number of foreign residents was almost 500,000, accounting for about $0.8 \%$ of the total population. Only in 1986, the first law recognizing the legal status to foreigners working and living in Italy was introduced. Few years later, 1990, the Italian government issued a law regulating immigration policy and implementing a quota system; based on the demand for labor of Italian firms, the Italian government had to set every year a maximum number of immigrants that can enter the country.

The main effect of these two first immigration laws was to grant amnesties that conferred legal status to more than 300,000 migrants already working in Italy. The low level of quotas, which were insufficient to satisfy the demand for foreign workforce, and the expectations of future amnesties increased the illegal entry of immigrants. In 1996 and 1998 two other amnesties were granted, regularizing respectively 250,000 and 218,000 undocumented foreign workers.

Since 1998, an immigrant who wants to reside and work legally in Italy is required to hold a permit of stay (before this law, legalization was acquired primarily via amnesties). The permit of stay however does not apply to all migrants: immigrants from countries that signed the Schengen Agreements do not need any permits to live and work in Italy and they can freely enter the country. ${ }^{33}$

The 1998 reform established a maximum period of non-employment following job loss for immigrants to be set equal to one year. In 2001 a new restrictive law passed and the maximum time without working was reduced to six months, past this period, the immigrant becomes unauthorized and he/she has to leave Italy. In the same year the biggest amnesty took place regularizing almost 650,000 undocumented foreign residents.

Overall Italian immigration amnesties involved almost 1.5 million individuals: it is clear that amnesties represented the main gateway into the country. In order to be eligible for regularization a migrant has to show a regular job offer.

The estimates on illegal migrants are based on the number of applications to amnesties, these measures are very noisy and range from 10 to 40 per cent of the legal workers, i.e. in

\footnotetext{
${ }^{33}$ Moreover countries belonging to the European Union are excluded. In the observation period (i.e. up to 2001), migrants from the following countries were exempted from the permit of stay regulation: Austria, Belgium, Denmark, Finland, France, Germany, Greece, Ireland, Luxembourg, Netherlands, Portugal, Spain, Sweden, United Kingdom.
} 
20011.4 million of migrants were present in Italy meaning that the estimates of illegal migrants are around 140,000 to 500,000 unauthorized migrant. (Venturini and Villosio, 2008; Fasani, 2010). Several institutions, such as Caritas of the national statistics office, ISTAT, also provide estimates of illegal migrants operating in the black economy. 